\title{
Using Augmented and Virtual Reality in Information Literacy Instruction to Reduce Library Anxiety in Nontraditional and International Students
}

Angela Sample

\section{ABSTRACT}

Throughout its early years, the Oral Roberts University (ORU) Library held a place of pre-eminence on campus. ORU's founder envisioned the Library as central to all academic function and scholarship. Under the direction of the founding dean of learning resources, the Library was an early pioneer in innovative technologies and methods. However, over time, as the case with many academic libraries, the Library's reputation as an institution crucial to the academic work on campus had diminished.

A team of librarians is now engaged in programs aimed at repositioning the Library as the university's hub of learning. Toward that goal, the Library has long taught information literacy (IL) to students and faculty through several traditional methods, including one-shot workshops and sessions tied to specific courses of study. Now, in conjunction with disseminating augmented, virtual, and mixed reality (AVMR) learning technologies, the Library is redesigning instruction to align with various realities of higher education today, including uses of AVMR in instruction and research and following best practices from research into serving

1. online learners;

2. international learners not accustomed to Western higher-education practices; and

3. learners returning to university study after being away from higher education for some time or having changed disciplines of study.

The Library is innovating online tutorials targeted for nontraditional and international graduate students with various combinations of AVMR, with the goal to diminish library anxiety. Numerous library and information science studies have shown a correlation between library anxiety and reduced library use, and library use has been linked to student learning, academic success, and retention. ${ }^{1}$

This paper focuses on IL instruction methods under development by the Library. Current indicators are encouraging as the Library embarks on the redesign of IL instruction and early development of inclusion of AVMR in IL instruction for nontraditional and international students.

\section{LITERATURE REVIEW}

The patron approaches the reference desk, with eyes downcast. In a voice so soft that it is barely above a whisper, the patron mumbles, "Is this where I can get help with research?"

Some variation on the above scenario is an occurrence long familiar to academic reference librarians. In 1986, Mellon put a name to this nervousness of patrons; she called it library anxiety. ${ }^{2}$

Dr. Angela Sample (asample@oru.edu) is Head of Access Services, Oral Roberts University 
Since then, librarians have implemented various measures to help put patrons at ease and minimize their library anxiety. Scholars have studied many of these measures aimed at reducing library anxiety, both to determine the efficacy of such interventions and to understand better the causes of library anxiety. This paper describes one library's intervention using a virtual-reality tour of the library to learn about some of the services available at the library prior to their initial visit in an attempt to reduce some aspects of their library anxiety.

\section{LIBRARY ANXIETY}

Library and information science (LIS) researchers have long recognized anxiety related to libraries and research can have a detrimental effect on students. Mizrachi described library anxiety as

the feeling of being overwhelmed, intimidated, nervous, uncertain, or confused when using or contemplating use of the library and its resources to satisfy an information need. It is a state-based anxiety that can result in misconceptions or misapplications of library resources, procrastination, and avoidance of library tasks. ${ }^{3}$

Since Mellon's theoretical framing of library anxiety in 1986, researchers have studied a number of library-related anxieties, including research anxiety, information literacy anxiety, library technophobia, and computer anxiety. Various studies have focused on different groups of students - freshmen, nontraditional students, and international students, to name a few - who may experience higher levels of library anxiety. Another area that has been of interest to researchers is the study of the efficacy of various measures aimed at reducing the library anxiety of students.

\section{Causes and Factors}

Researchers have found several causes of library anxiety. In her seminal article, Mellon used a grounded theory approach to understand and "describe students' fear of the library as library anxiety." 4 Mellon noted most of the students in her study described their feelings as being lost in the library, which Mellon stated "stemmed from four causes: (1) the size of the library; (2) a lack of knowledge about where things were located; (3) how to begin; and (4) what to do." ${ }^{5}$ Head and Eisenberg also found a majority of students (84 percent) had difficulties in knowing where to begin. ${ }^{6}$ Bostick and later Jiao and Onwuegbuzie named "five general antecedents of library anxiety ... namely, barriers with staff, affective barriers, comfort with the library, knowledge of the library, and mechanical barriers."7

Barriers with staff are the feelings students have regarding the accessibility and approachability of library staff. ${ }^{8}$ Affective barriers are students' self-perceptions of their competence in using the library and library resources. Affective barriers' arise from feelings of inadequacy and can be heightened by the perception that others possess library skills that they alone do not. ${ }^{9}$ Comfort with the library deals with the student's perception of the library as a "safe and comforting environment."10 Knowledge of the library is students' knowledge of "where things are located and how to find their way around in the building." 11 Mechanical barriers refer to students' perception of the reliability of machines in the library (e.g., copiers, printers, computers, etc.). ${ }^{12}$

Researchers focused on investigating the information-seeking behavior of students have identified stages of library anxiety. In her work, Kuhlthau identified six stages of information seeking in 
which students may experience library anxiety: task initiation, topic selection, prefocus exploration, focus formulation, information collection, and search closure. ${ }^{13}$ In Blundell's presentation of her theoretical model of the academic information search process (AISP) of undergraduate Millennial students (figure 1), she described the varying levels of anxiety students may feel throughout this process depending upon their success at finding needed information. ${ }^{14}$ Anxiety at Stage 2: Development/Refinement "ranges from mild to extreme, depending on the success of the student's AISP in finding information he/she believes is appropriate for addressing the academic need." 15 At Stage 3, "Based on information located through the AISP in Stages $1 \& 2$, [the] student either fulfills [the] academic need with minimal anxiety, refocuses AISP with mid to high-level anxiety, or abandons the academic need completely with high/extreme levels of anxiety." 16

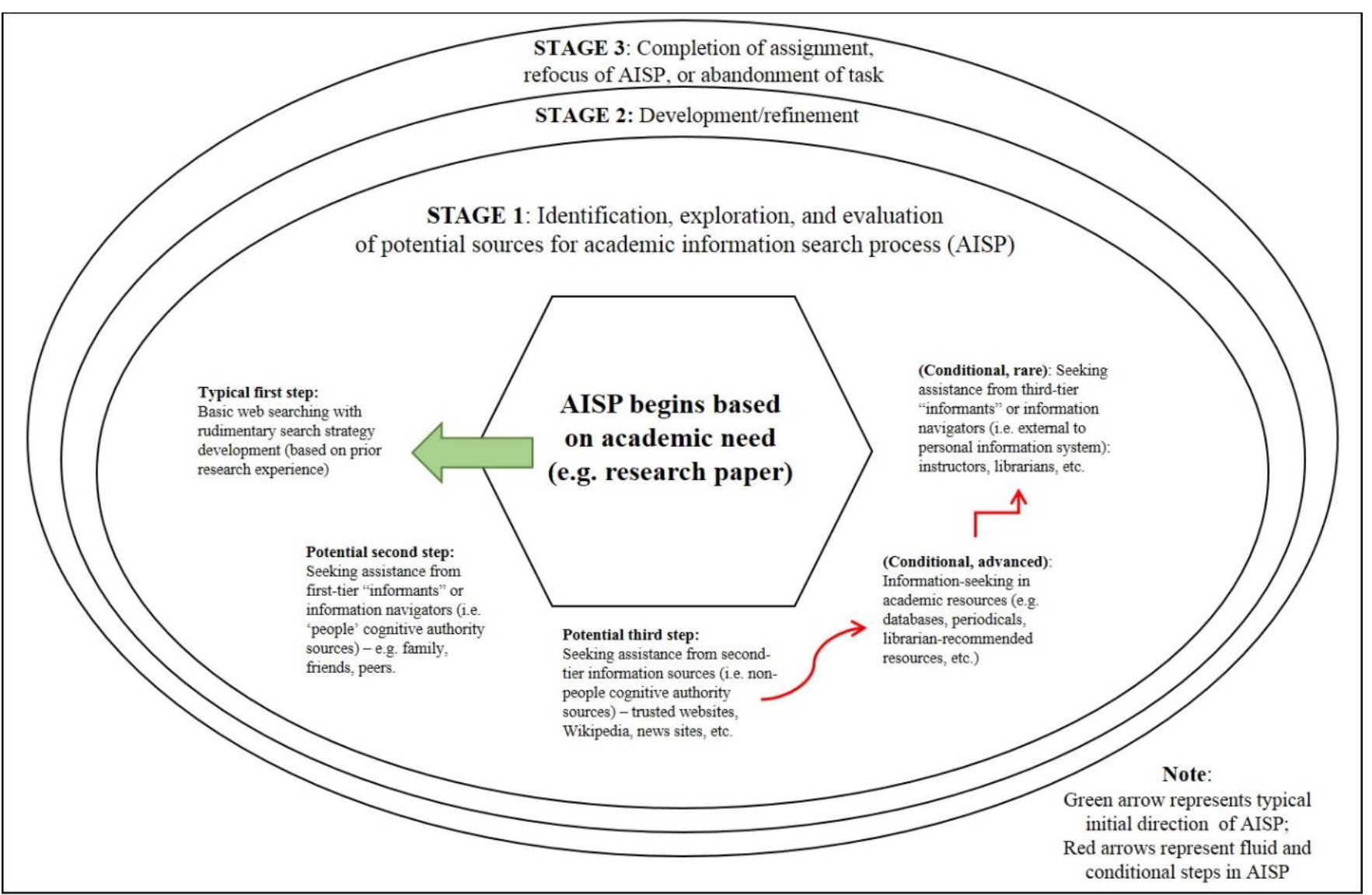

Figure 1. Blundell AISP Model. ${ }^{17}$

Although Blundell studied undergraduate Millennial students' information-seeking behaviors, the same behaviors may also be descriptive of other groups of students. Blundell omitted anxiety at or prior to Stage 1 when the assignment is received by the student. One reason for the omission of anxiety in Blundell's model at Stage 1 may be a seemingly paradoxical finding by many researchers regarding students' inflated belief in their research skills as compared to their actual level of information literacy (IL) skills. ${ }^{18}$ Students with a high self-assessment of their IL skills may feel confident at the onset of research, only experiencing anxiety when encountering low success rates when searching for information or when experiencing information overload. However, many other students may experience anxiety at the onset of receiving an assignment, particularly on a 
topic in which they have little or no knowledge. Others may experience anxiety if they realize they do not know where to look for information, how to use library research tools, or feel apprehension at the thought of asking for help from a librarian. For example, library anxiety can result from the requirements of the assignment; most professors require peer-reviewed sources. Many new students do not know what a peer-reviewed source is, much less how to find one. Indeed, many of the causes of library anxiety described from Mellon's and later Jiao's and Onwuegbuzie's work can be positioned throughout all six of Kuhlthau's and all three of Blundell's stages of information seeking and could explain some of the potential steps Blundell noted in her model.

\section{Negative Effects}

In addition to the obvious discomfort students might feel, library anxiety, as with other forms of anxiety, can have a detrimental effect on students' academic performance. As Mellon noted, "Students become so anxious about having to gather information in a library for their research paper that they are unable to approach the problem logically or effectively." 19 The findings from Jiao's and Onwuegbuzie's numerous studies support the negative effect library anxiety can have on students' academic performance in various ways, including research performance, research proposal writing, and study habits. ${ }^{20}$ Research has also shown the link between higher levels of library anxiety and avoidance of the library. ${ }^{21}$ Avoidance of the library could hinder students' academic performance or retention; studies have linked library use to higher GPAs and increased retention rates. ${ }^{22}$ Other negative effects of library anxiety include the reluctance of students to ask for help from a librarian and the tendency to procrastinate until it is too late to do well on assignments. When library anxiety is at a level high enough to cause students to enter a panic mode, logical thinking, the ability to apply existing skills, and building or acquiring new skills can be impaired.

\section{At-Risk Student Groups}

Acknowledging the negative effects library anxiety can have on students' academic performance, several studies have looked to determine whether particular demographic groups of students experience library anxiety at higher rates and what factors or causes may be most prevalent in the causes of library anxiety for a particular group. In one study conducted by Jiao, Onwuegbuzie, and Lichtenstein, students who fell into the following groups tended to have the highest levels of library anxiety: "male, undergraduate, not speak English as their native language, have high levels of academic achievement, be employed either part- or full-time, and visit the library infrequently." 23 Some studies have focused on learning more about the library anxiety of a particular group. Some of the groups investigated include graduate, international, and nontraditional students. Still others have focused on possible racial differences in the prevalence of library anxiety.

Although a few studies have found library anxiety to be higher for undergraduate students than graduate students, one of the most often-studied groups at risk for library anxiety has been graduate students. ${ }^{24}$ These researchers have looked at a number of factors in relation to graduate students' library anxiety. In an early study, they found graduate students with the preferred learning style of visual learners tend to have higher levels of library anxiety. ${ }^{25}$ In another study of graduate students, they examined the relation between library anxiety and trait anxiety, defined as "the relative stable proneness within each person to react to situations seen as stressful." ${ }^{26}$ Jiao and Onwuegbuzie, together with Bostick, investigated the potential relationship between race and library anxiety in 2004, which study they replicated in 2006. In both, the researchers found 
Caucasian American graduate students reported higher levels of library anxiety than their African American counterparts. ${ }^{27}$

Another group frequently examined in library anxiety studies is international students. Mizrachi noted "studies involving international students in American universities consistently show their levels of library anxiety to be much higher than their American peers." ${ }^{28}$ Onwuegbuzie and Jiao found international ESL students "had higher levels of library anxiety associated with 'barriers with staff,' 'affective barriers,' and 'mechanical barriers,' and lower levels of library anxiety associated with 'knowledge of the library' than did native English speakers." ${ }^{29}$ Later, Jiao and Onwuegbuzie found the most prevalent causes of library anxiety for international students were mechanical barriers (library technology) as the greatest source, followed by affective barriers. ${ }^{30}$ In the more recent pilot study by Lu and Adkins, the greatest barriers for international students were affective and staff barriers, while mechanical barriers, such as technologies, were no longer a significant cause of anxiety for most. ${ }^{31}$

Collins and Veal found adult learners in their study had the highest degree of library anxiety pertaining to affective barriers. ${ }^{32}$ In their study, Kwon, Onwuegbuzie, and Alexander revealed graduate students who had higher levels of library anxiety resulting from affective barriers and knowledge of the library had weaker critical-thinking skills, lower self-confidence, less inquisitiveness, and reduced systematicity ("less disposed toward organized, logical, focused, and attentive inquiry"). ${ }^{33}$ Kwon found similar results in undergraduate students. ${ }^{34}$

\section{Interventions}

Recognizing the multiple causes and multidimensional aspects of library anxiety, librarians have devised a number of interventions aimed at addressing one or more of its causes. Some of the means to address barriers with staff have focused on outreach, engaging library instruction, online presence, and other similar efforts to reach students and provide needed support for students' research. Librarians have used information literacy instruction (ILI), reference desk consultations, and print and online guides to address library anxiety stemming from affective barriers, knowledge of the library, and even the mechanical barriers arising from lack of technology skills.

A common intervention is ILI, which several studies have found to have some success in reducing students' library anxiety. Bell explored students' levels of library anxiety before and after a onecredit IL course. ${ }^{35}$ Platt and Platt examined the efficacy of two 50-minute ILI sessions, required of students enrolled in the Research Methods in Psychology course, in reducing library anxiety, which found "the greatest changes ... were related primarily to knowledge of what resources are available in the library and how to access them." ${ }^{36}$ In contrast to the typical one-session IL class, Fleming-May, Mays, and Radom investigated and found a three-workshop instruction model correlated with students' increased confidence in using the library and lessening library anxiety. ${ }^{37}$ Notwithstanding the benefits of library instruction sessions for students in relieving library anxiety, Pellegrino found students were far more likely to ask a librarian for help when their instructor, rather than a librarian, encouraged or required them do so. ${ }^{38}$

By familiarizing students with the location and arrangement of library services in the building, library orientations have been found to help relieve library anxiety. ${ }^{39}$ Library orientations primarily aim to address one of the causes of library anxiety: a lack knowledge of the library. These orientations often introduce students to various library staff, which may also help with the dimension of library anxiety due to barriers with staff. 
Other interventions have been attempted with some success. Martin and Park found students were more apt to request assistance from the librarian if persuaded the consultation would save time. ${ }^{40} \mathrm{McDaniel}$ found in a study of graduate students that the use of peer mentors was effective in reducing affective barriers. ${ }^{41}$ Robbins discussed the use of library events to help ease students anxiety, but found in the follow-up survey many students were unaware of the events. ${ }^{42}$ DiPrince et al. discussed ways the use of a print guide can help alleviate library anxiety. ${ }^{43}$

\section{ORU LIBRARY}

\section{Oral Roberts University}

The ORU Library serves the students, faculty, and staff of Oral Roberts University (ORU). ORU is a small, private, not-for-profit, liberal arts college located in Tulsa, Oklahoma. Founded in 1963 by Oral Roberts, enrollment is approximately 3,600 students. ORU is an interdenominational Christian institution focused on a whole-person education of spirit, mind, and body. ORU offers more than 150 majors, minors, and pre-professional programs in a range of degree fields, from business, biology, engineering, nursing, ministry, and more. ${ }^{44}$

\section{History}

"The first building will be the Library which is the core of the whole academic structure."45

-Oral Roberts (1962)

From the founding of ORU, Founder Oral Roberts had a vision of the library's centrality to academics. ${ }^{46}$ This set a precedent early in the history of ORU Library of the importance of the library to the academic work of the students and faculty of ORU. Expanding on traditional views of the function of an academic library to serve mainly as the repository of books and articles, through the vision of early library administrators, ORU Library emerged as one of the early adopters of electronic technology with the DAIRS (Dial Access Information Retrieval System) computer. ${ }^{47}$

Throughout the years, due to a number of factors, the ORU Library receded from the forefront of pre-eminence in academics on campus. Library practices followed the general trend of academic libraries. The ORU Library continued to acquire needed materials (e.g., books, journals, access to databases). Library instruction likewise kept up with current models of instruction. The typical method of instruction to undergraduates has been teaching one or two sessions to a class at the request of the instructor. On largely the efforts of the instruction librarian, IL became a required component of undergraduate education at ORU. With rare exceptions, undergraduate students at ORU are required as a part of Comp 102: Composition II to attend two sessions of an IL course. Other forms of ILI include workshops and sessions for undergraduates working on their senior papers and other sessions for graduate and postgraduate students, all typically at the request of the instructors of classes.

With the new addition of augmented, virtual, and mixed reality (AVMR) learning technologies, at the behest of their dean, ORU librarians have begun to look at ways to incorporate these technologies into their classes and daily work. Several ORU instructors are using AVMR technologies in their classes. ${ }^{48}$ To help prepare students for the use of these technologies in their classes, one ORU instruction librarian has begun to introduce students to AVMR technologies. Other ORU instruction librarians are exploring ways to use AVMR technologies to create visualizations of library and research concepts, such as a 3D visualization of how Boolean logic 
works in database searches. ORU instruction librarians are also exploring ways to incorporate AVMR technologies into a new program of online ILI. Although still in very early stages of planning, the proposed online ILI will include a virtual tour of the library. This paper focuses on the implementation and early feedback from a formative assessment on a virtual tour of the ORU Library.

\section{ORU Modular Students}

In addition to traditional 15-week semesters, two colleges at ORU offer graduate modular programs, the College of Education and the College of Theology and Ministry. Many of the students who enroll in these programs are nontraditional students who are returning to college after some time. Several of these students work full-time jobs and have family obligations in addition to their academic work. Often, these students are not local to the Tulsa campus; several are US students who live out of state and many others are international students.

The modular classes offered by both programs can be a hybrid of online and modular format. The College of Theology and Ministry offers one-week courses on campus; the College of Education offers two-and-a-half-day on-campus classes. Modular classes are intensive due to the compressed nature of the curriculum. Often, modular students are visiting campus for the first time, and in addition to locating their classes, are very busy with coursework. Adding to these pressures, modular students may be using computer technologies in new ways. Navigating the Library's resources is yet another stressor for many of these students. For students who are not familiar with the operations of an academic library, they may not be aware of Library services nor how to access those services.

\section{The Project}

In January 2017, the Global Learning Center opened on the campus of ORU. One hallmark of this renovated structure is the integration of AVMR technologies. ${ }^{49}$ Despite several professors on campus from various disciplines and colleges implementing AVMR into their curriculum, students' use of the facilities was somewhat lower than had been hoped. In the Fall 2018 semester, the idea of creating a virtual tour of the ORU Library arose from a conversation between the author and a colleague, Dan Eller. Eller described an online ILI course he envisioned for ORU's graduate Theology modular students. As a part of this course, he envisioned a virtual tour that could help students by reducing their library anxiety. Early in 2019, ORU's associate vice president of technology and innovation, Michael Mathews, contacted Dr. Mark Roberts, dean of learning resources (of which the ORU Library is a part) to propose making AVMR learning technologies available through the ORU Library. Dean Roberts agreed and created an AVMR team of library faculty to oversee this project.

In the Spring 2019 semester, the ORU IT department sent one of their employees, Stephen Guzman, to work with the Library's AVMR team to set up an AVMR station and work in the Library to help make these new technologies available and known to ORU students. In addition to other AVMR projects Guzman helped the Library's AVMR team begin, he volunteered to take the 360 images when he learned of the library's desire to create a virtual tour of the Library. Guzman also helped in the selection of editing software, 3DVista, for which the Library acquired a license.

Working with the 360 images Guzman took and stitched together, the author used 3DVista to create a virtual tour of the Library. This software allows for the addition of elements to the 360 images that make up the virtual tour to enhance the viewer's experience and to provide 
information and hyperlinks to external webpages with more information. Some of the elements added to the ORU Library Virtual Tour are hotspots that enable a viewer to move from one area to another, icons that present pop-up windows with more information, and other icons that link to the online profiles of various library faculty. Throughout the tour, consistent use of icons for the same functions is maintained. For example, icons with arrows allow the viewer to move from one location to another (figure 2), while icons with question marks displayed over Library personnel (figure 3) open the personnel's profile webpage when clicked. Icons that contain the letter "i" feature pop-up windows with information and related links.

The tour begins from outside the building so new visitors will be able to recognize the building when they arrive on campus (figure 4). Viewers can navigate through subsequent 360 images by clicking on the arrow icons so the viewer virtually travels the same path they will follow to enter the library when on campus. There are two other options to navigate the tour. The viewer can click on the small icons of scenes displayed on the left side of the screen to move to another area. The floor plans displayed at the upper right of the screen have red dots indicating the location of various scenes and, when clicked, move the viewer to that scene.

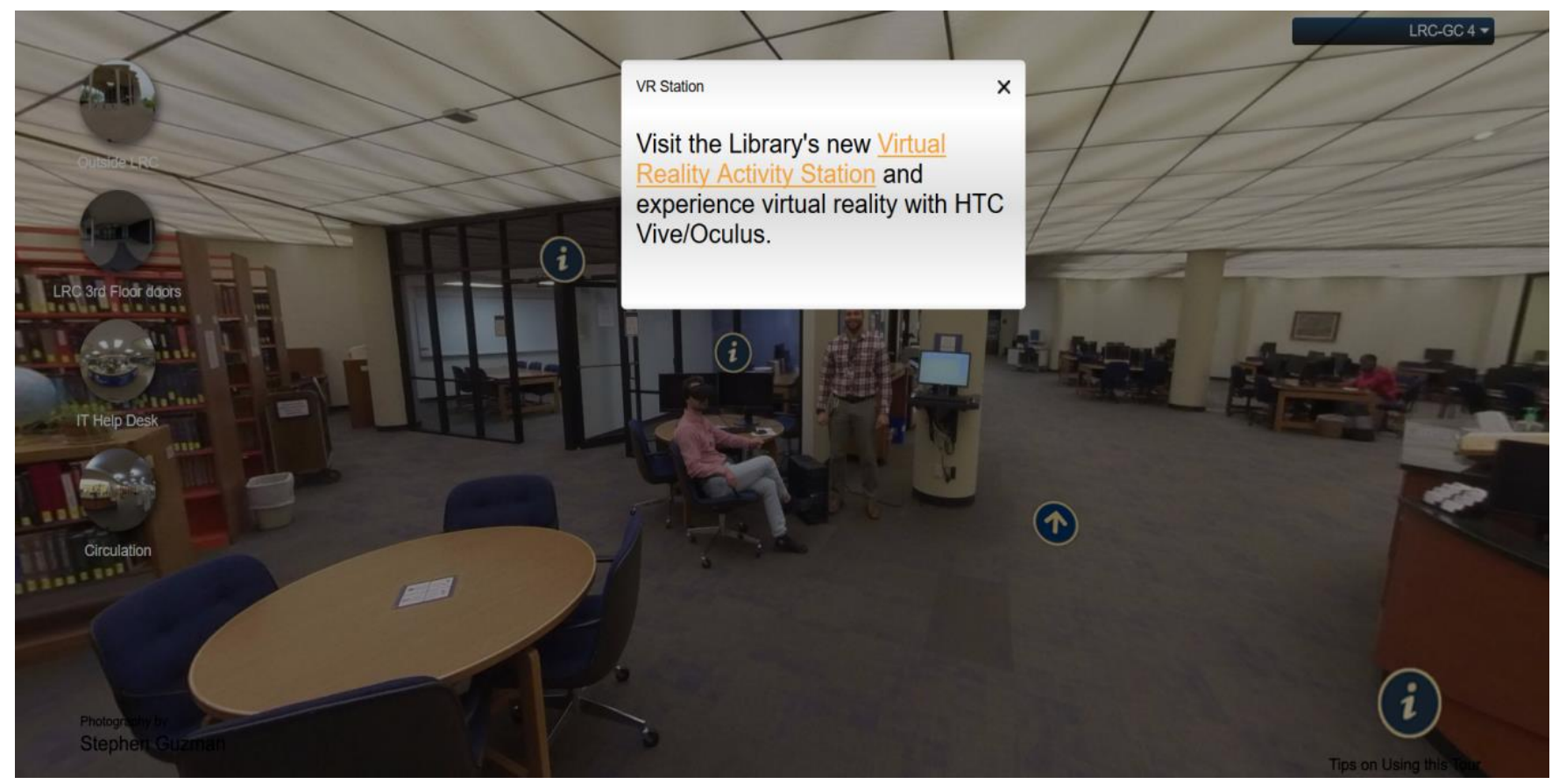

Figure 2. AVMR Station near the Reference Desk, ORU Library Virtual Tour.

Other elements of the tour include small icons of the scenes on the left of the screen. Beneath these icons are the names of the various areas. The title of the current scene appears in yellow lettering, providing information to help orient the viewer. Small floorplans located in the upper right side of the screen offer additional information on the location of the area (figure 3). Viewers can toggle these floorplans on and off. Another feature supplying location information is the dropdown menu for the floorplans (the dark blue bar at the upper right of the screen) which shows the floor level of the building on which the area is located. In the lower right of the screen, an information icon is available with details on what behavior to expect when clicking on icons and a description of the various ways to navigate the tour. 


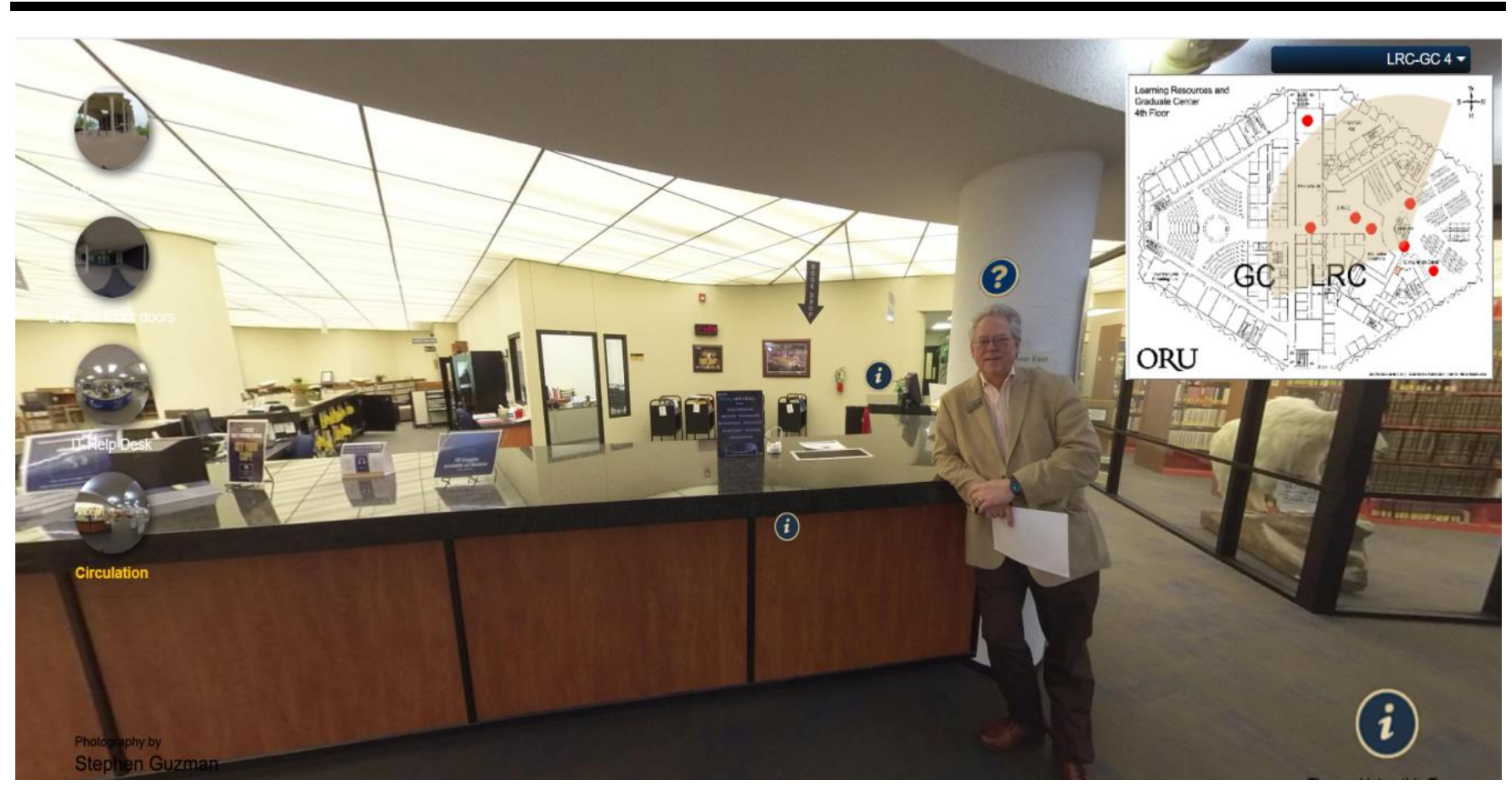

Figure 3. Dean Mark Roberts near Alexa and the Self-Checkout station at the Circulation Desk, ORU Library Virtual Tour.

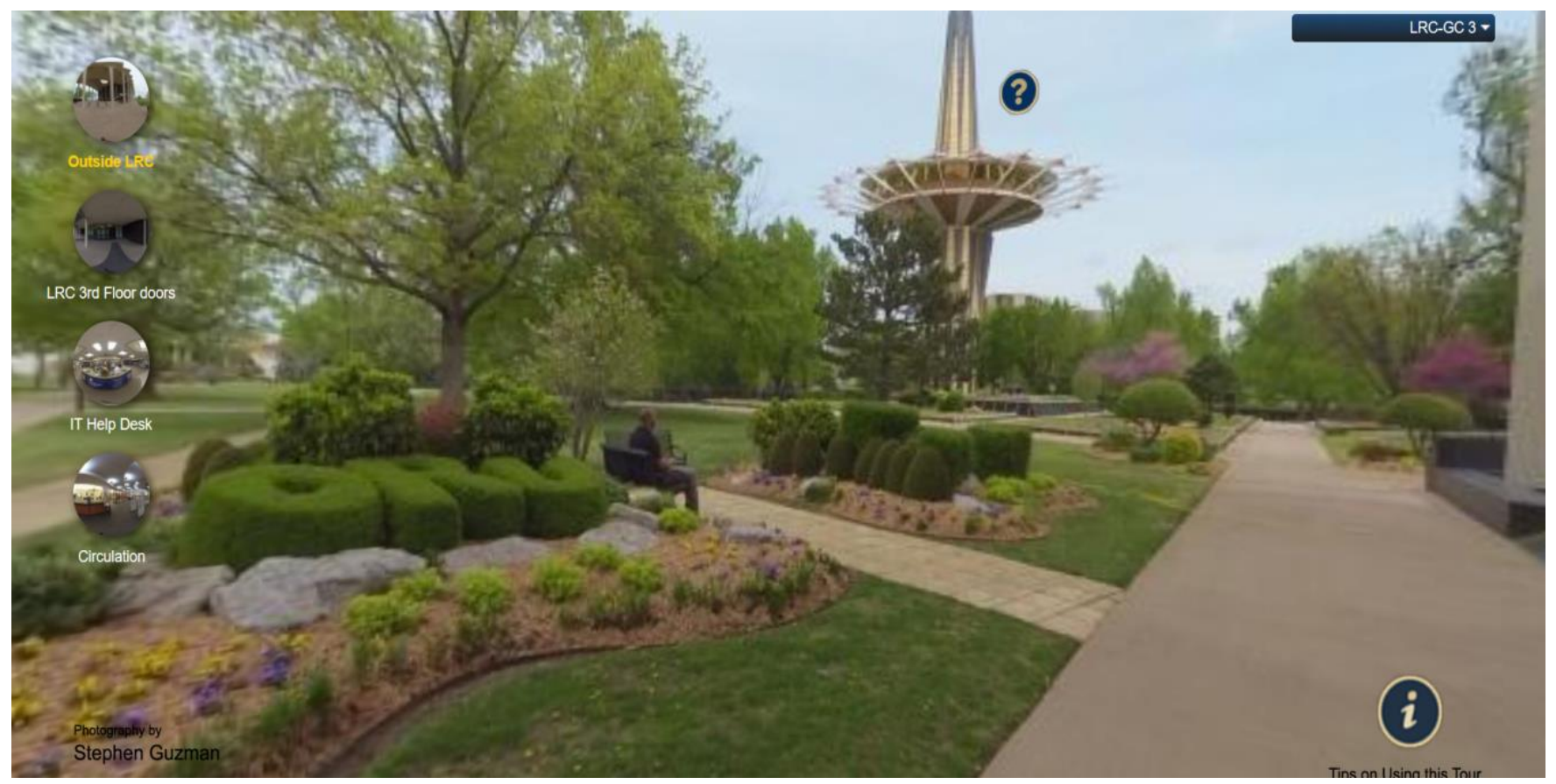

Figure 4. ORU campus, ORU Library Tour. 


\section{METHODOLOGY}

The aim of the virtual tour of the library is to reduce several dimensions of students' library anxiety. The primary goal of the tour is to reduce anxiety related to knowledge of the library by familiarizing students with images and information regarding the building prior to their arrival on campus. Another aim is to reduce barriers with staff, which we address by proving information along with images of library faculty. Affective barriers and mechanical barriers are two of the most prevalent causes of library anxiety, which the intervention of the tour does not directly address. The hope is, however, that with the minimization of any anxiety stemming from knowledge of the building and barriers with staff, students will be encouraged to consult with librarians, particularly as information on the variety of ways to contact librarians is included on the information pop-up window on the Reference Desk.

\section{Pre- and Post-Surveys}

The pre- and post-surveys administered to students included 42 statements from Bostick's Library Anxiety Scale. Bostick's Library Anxiety Scale, developed in 1992, is a 5-point Likert scale survey instrument that contains 43 statements. The pre-survey also contains demographic questions. The one statement omitted from Bostick's original survey was number 40, "The change machines are always out of order," as the ORU Library does not have change machines. ${ }^{50}$ With the exception of the demographical questions, the post-survey is the duplicate of the pre-survey, with the same 42 statements. Although several researchers have adapted Bostick's Library Anxiety Scale, such as Blundell's adaptation to add "elements related specifically to information technology (both hardware such as computers, and software such as online research databases)," 51 for the purposes of this preliminary inquiry, the researcher decided to use the original questions from the Library Anxiety Scale. The original statements were used because reduction of library anxiety stemming from information technology use was not a goal of this study.

\section{Administration of Survey}

A link to the pre-survey was posted on the homepage of the ORU Library. The author sent email invitations containing a link to the pre-survey to students enrolled in the June 2019 summer modular Theology classes. The author met with groups of Education modular students during the week they were on campus (June 24-30, 2019) to recruit participation. In a library session, another librarian encouraged her modular students to participate in the study.

At the end of the pre-survey, a unique number and instructions to note the number were provided to participants to be used to log in to the post-survey. The link to the virtual tour appeared on the final screen of the pre-survey. The link to the post-survey was provided on the same page as the virtual tour, allowing participants to navigate to the post-survey when desired.

The surveys asked for no identifying information; however, the unique number provided on the pre-surveys and entered by the participants on the post-surveys allowed the researcher to link the participants' responses to both surveys. Once the results were downloaded, each of the participants' pre- and post-survey responses were coded P1 through P7 to track any potential effects of the virtual tour on participants' responses. Because of the low rate of participation, formal statistical analyses were not applied to these findings. The results were examined in two ways. Each participants' pre- and post-survey responses were compared to determine if responses changed from pre- to post-survey. The total number of responses on each point of the Likert scale 
to each of the 42 statements were examined to determine trends in participants' levels of library anxiety.

\section{RESULTS}

Although approximately 100 students enrolled in either the graduate Theology or graduate Education modular classes visited the campus June 24-30,2019, participation in this preliminary study was extremely low. To date only seven participants have completed both the pre- and postsurveys. The responses from this formative assessment will be used by the ORU Library to guide future iterations of the virtual Library tour and inclusion in ILI. The following discusses initial findings from the pre- and post-surveys.

Most of the participants reported little or no discomfort or anxiety with using the Library. All participants indicated they are US citizens, and all indicated some level of familiarity with the Library. Four reported they had often visited the Library, three responded they had visited the Library previously, but not often. Of the seven participants, five indicated they are graduate students, one marked "other," and one reported doctoral-student status. Ages of the participants varied from one at 20-29, one 30-39, two 40-49, and three at 50 years or over. The following describes the effect the virtual tour of the Library had on participants' responses. Interestingly, one participant showed no change in responses from pre- to post-survey. Note: Bostick's original categorization of the statements have been retained for all 42 of the statements on both instruments.

\section{Knowledge of the Library}

The principal aim of the virtual tour was to reduce library anxiety related to knowledge of the library by acquainting students with "where things are located and how to find their way around in the building." 52 Bostick categorized 5 of the 42 statements as knowledge of the library. Based on participants' responses, there is some indication the tour did help acquaint students with the library. The changes in participants' responses showed a greater positive trend after viewing the virtual tour; although on two statements, responses showed a negative trend (table 1). Table 1 shows the questions on which participants had a change in their responses from pre- to postsurvey. The number in the Positive column indicates the number of participants whose responses displayed a favorable change in the perceptions of participants to that statement following the virtual tour. The number in the Negative column shows the number of participants whose responses on the post-survey showed a negative effect of the virtual tour on their responses.

\begin{tabular}{lcr}
\hline \multicolumn{1}{c}{ Statement } & Positive & Negative \\
\hline I don't feel physically safe in the library. & 1 & 1 \\
I enjoy learning new things about the library. & 3 & 1 \\
I want to learn how to do my own research. & 1 & \\
The library is a safe place. & 2 \\
The library is an important part of my school. & Totals & 9 \\
\hline
\end{tabular}

Table 1. Statements in knowledge of the library category, which showed change on post-survey.

The number of responses of strongly disagree statements in this category were unchanged from pre- to post-survey. The only statement that received any responses of strongly disagree was five 
to the statement "I don't feel physically safe in the library." Taken together with the two responses of disagree to this statement, all the participants feel safe in the library. To the statement "The library is a safe place," all seven participants answered either agree (five on pre-survey, four on post-survey) or strongly agree (two on pre-survey, three on post-survey) (figure 6).

Curiously, responses to "I enjoy learning new things about the library" changed from no responses of disagree on the pre-survey to one response of disagree on the post-survey. The other shift in the number of responses of disagree was on the statement "The library is an important part of my school" (two on pre-survey, one on post-survey), indicating a slight improvement (figure 5).

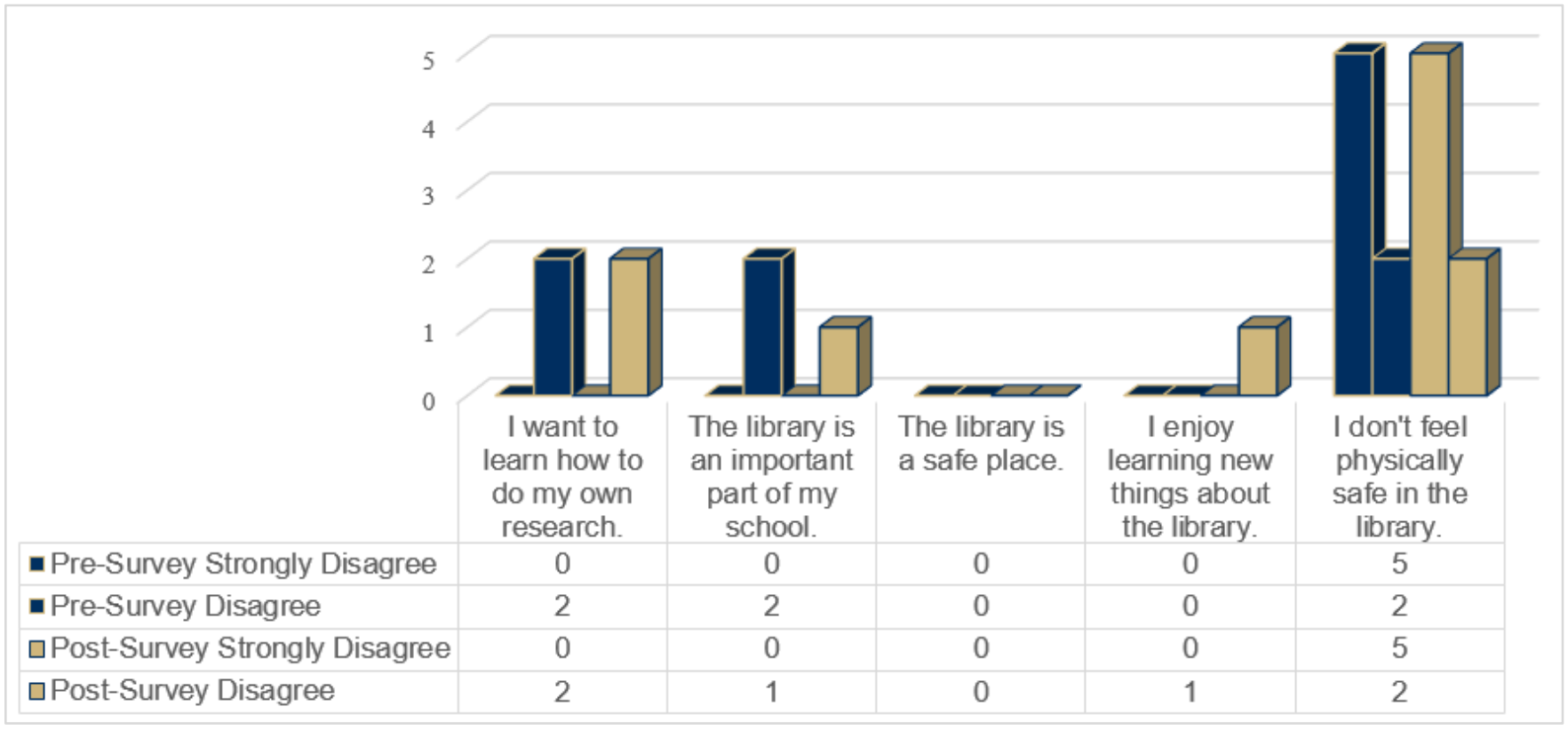

Figure 5. Comparison of strongly disagree and disagree responses in knowledge of the library category.

To the statements in this category, none of the respondents replied undecided, except to the statement "I enjoy learning new things about the library." There was one undecided response on the pre-survey and no responses of undecided on the post-survey to this statement. The other change in this category was to the statement "The library is an important part of my school," which moved from no responses of undecided on the pre-survey to one undecided on the postsurvey.

The respondents, for the most part, wanted to learn to do their own research, with five responses of agree or strongly agree on both the pre- and post-surveys. Five of the participants felt the library is of importance (one agree and four strongly agree). Six of the seven participants reported they enjoy learning new things about the library. The shift in responses from five agree and one strongly agree on pre-survey to two agree and four strongly agree indicates the tour might have affected participants' views on this statement (figure 6). 


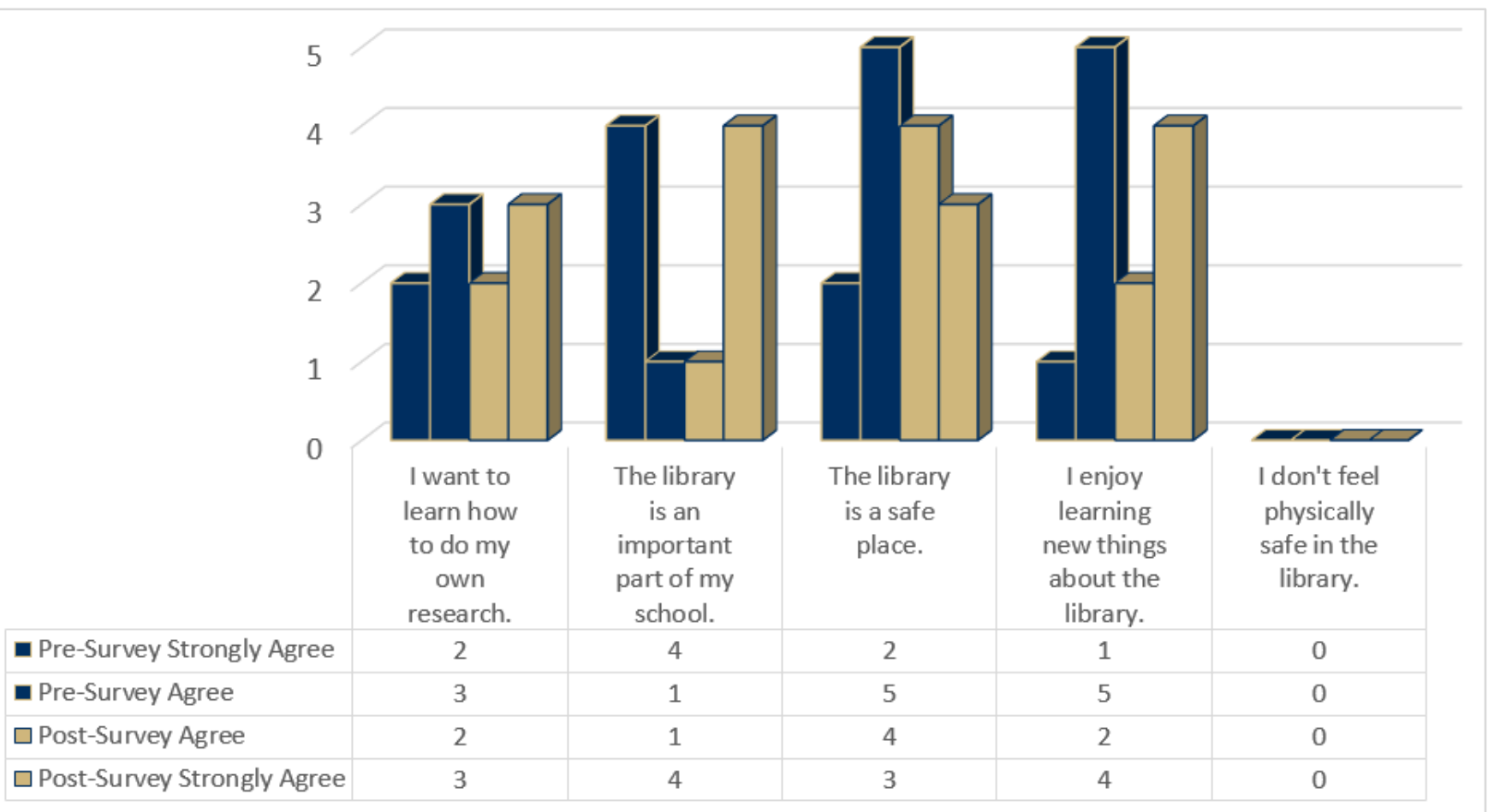

Figure 6. Comparison of strongly agree and agree responses in knowledge of the Library category.

\section{Affective Barriers}

While not a direct goal of the virtual tour, the responses of participants showed the most gains on the post-survey within the category of affective barriers. This seems to indicate that viewing the virtual tour improved students' self-perceptions of their competence in using the library and library resources. Out of the 42 statements on each of the instruments, 12 are in Bostick's category, affective barriers.

The statements in table 2 are those on which participants had a change in their responses from pre- to post-survey. The numbers in the positive column indicate the number of participant responses, which improved on the post-survey. A number in the negative column indicates participants' post-survey responses that moved in a negative direction.

\begin{tabular}{lll}
\hline \multicolumn{1}{c}{ Statement } & Positive & Negative \\
\hline A lot of the university is confusing to me. & 2 & \\
I am unsure how to begin my research. & 2 \\
I can never find things I need in the library. & 3 \\
I don't know what resources are available in the library. & 2 \\
I don't know what to do next when the book I need is not on the shelf. & 1 \\
I feel comfortable using the library. & 3 \\
I get confused trying to find my way around the library. & 2 \\
I'm embarrassed that I don't know how to use the library. & 1 & 1 \\
The directions for using the computers are not clear. & & 17 \\
\hline Totals & & 1 \\
\hline
\end{tabular}

Table 2. Statements in affective barriers category, which showed change on post-survey. 
Looking at the responses to statements in this category reveals some possible effects of the tour and some potential areas of library anxiety. The responses to "I don't know what resources are available in the library" were split on the pre-survey, with three responses of agree, one of strongly agree, one undecided, one of strongly disagree, and two of disagree. The post-survey responses showed almost no change; the only change was one additional response of undecided, with no strongly agree responses (figures 7.1, 8.1, 9.1). These findings indicate more information on what sources are available to patrons may be needed on the virtual tour.

Most of the respondents indicated confidence about where to begin research. On both pre- and post-surveys, there were five responses of strongly disagree or disagree to the statement "I am unsure how to begin my research" (figure 7.1). Most indicated they feel confident in using the library based on the responses to the statements "I'm embarrassed that I don't know how to use the library," "I feel comfortable using the library," "I can never find things in the library," and "I get confused trying to find my way around the library" (figures 7.1, 7.2, 9.1, 9.2). Responses were equally positive to the statements "The library won't let me check out as many items as I need," "A lot of the university is confusing to me," "I don't know what to do next when the book I need is not on the shelf," and "I can't find enough space in the library to study" (figures 7.1, 7.2, 8.1, 8.2, 9.1, 9.2).

Responses were divided on the statement "I feel like I'm bothering the reference librarian if I ask a question" (figures 8.2, 10.2). This finding needs further research to determine what is causing students to feel reluctance to ask the librarian for assistance.

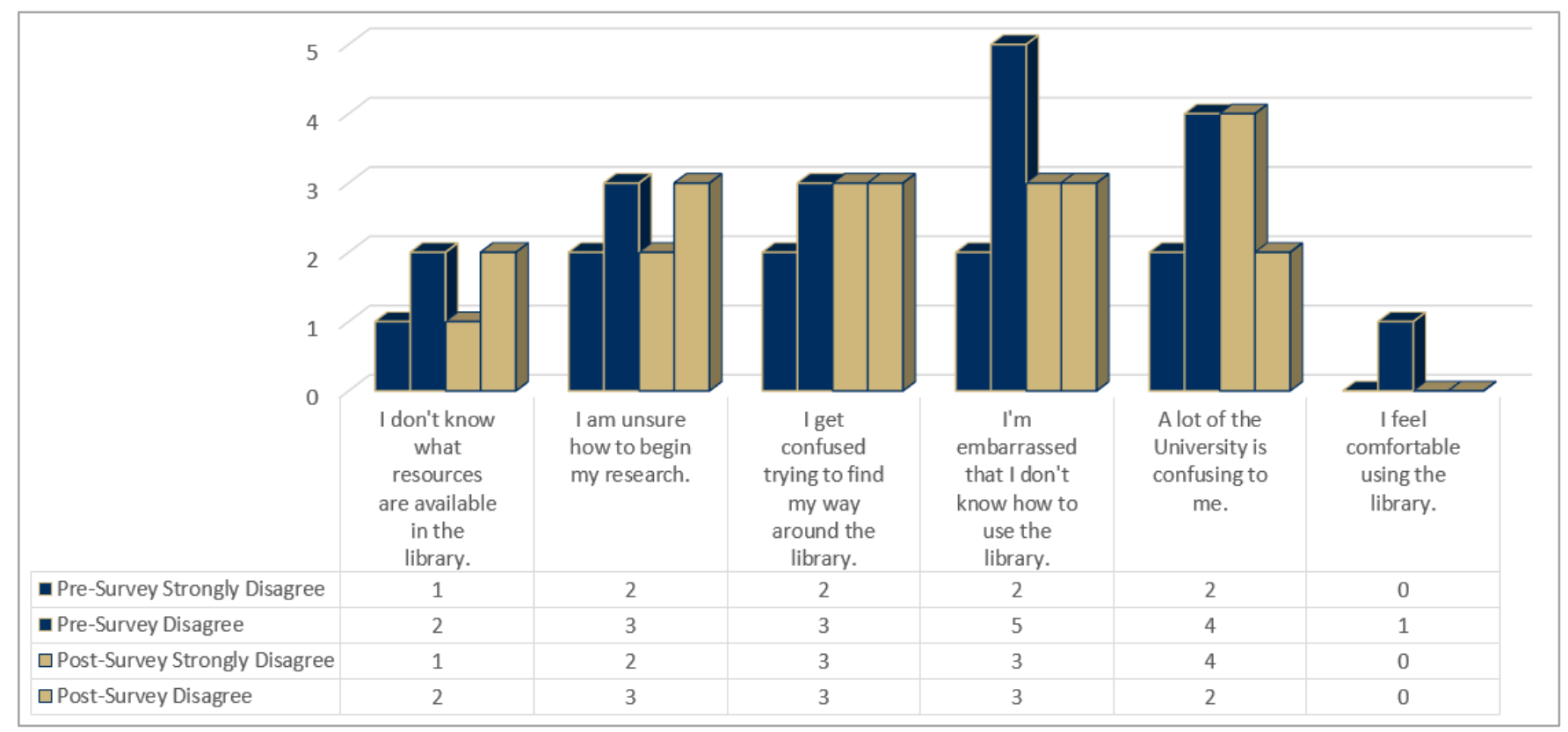

Figure 7.1. Comparison of strongly disagree and disagree responses in affective barriers category. 


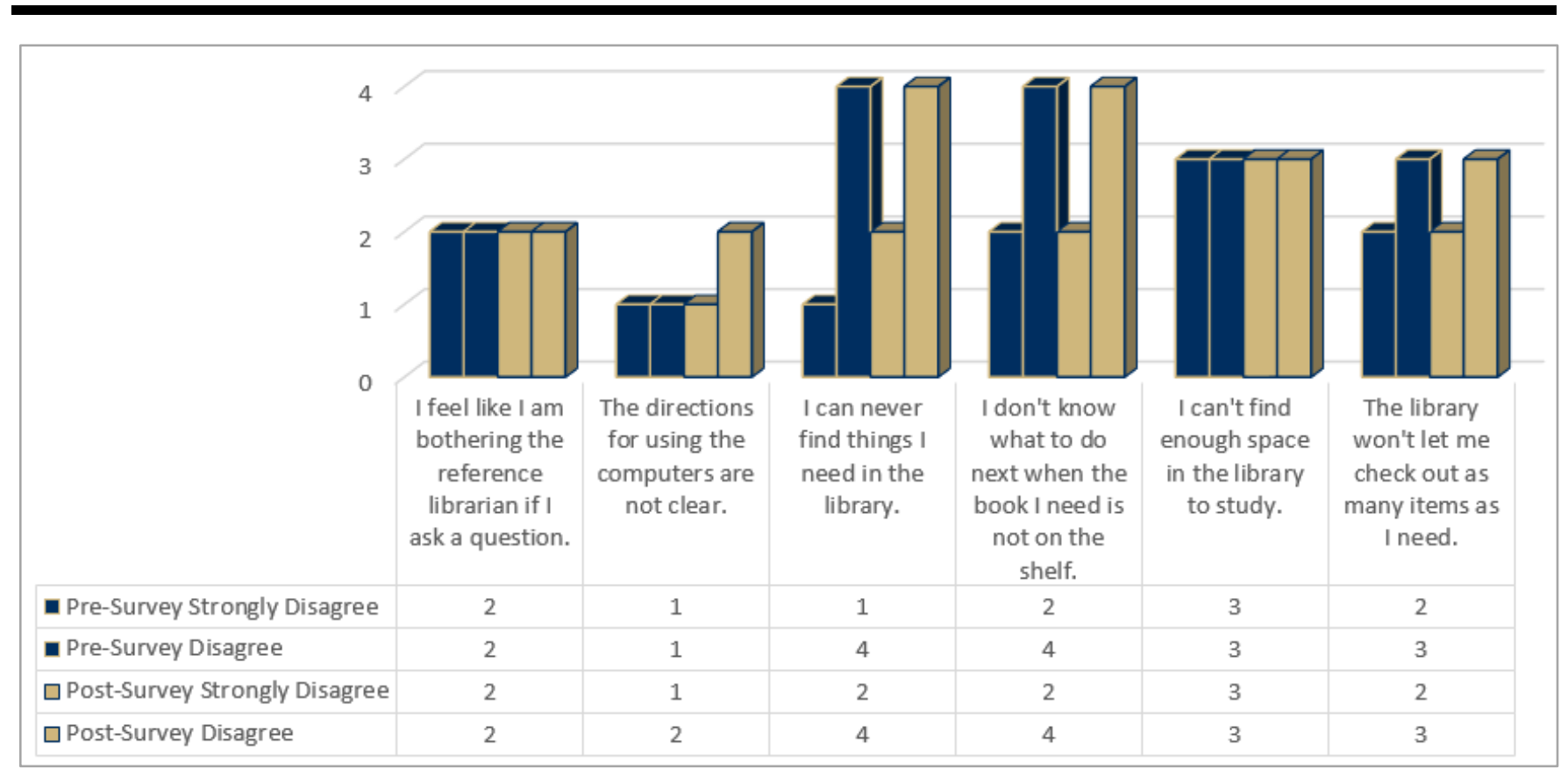

Figure 7.2. Comparison of strongly disagree and disagree responses in affective barriers category.

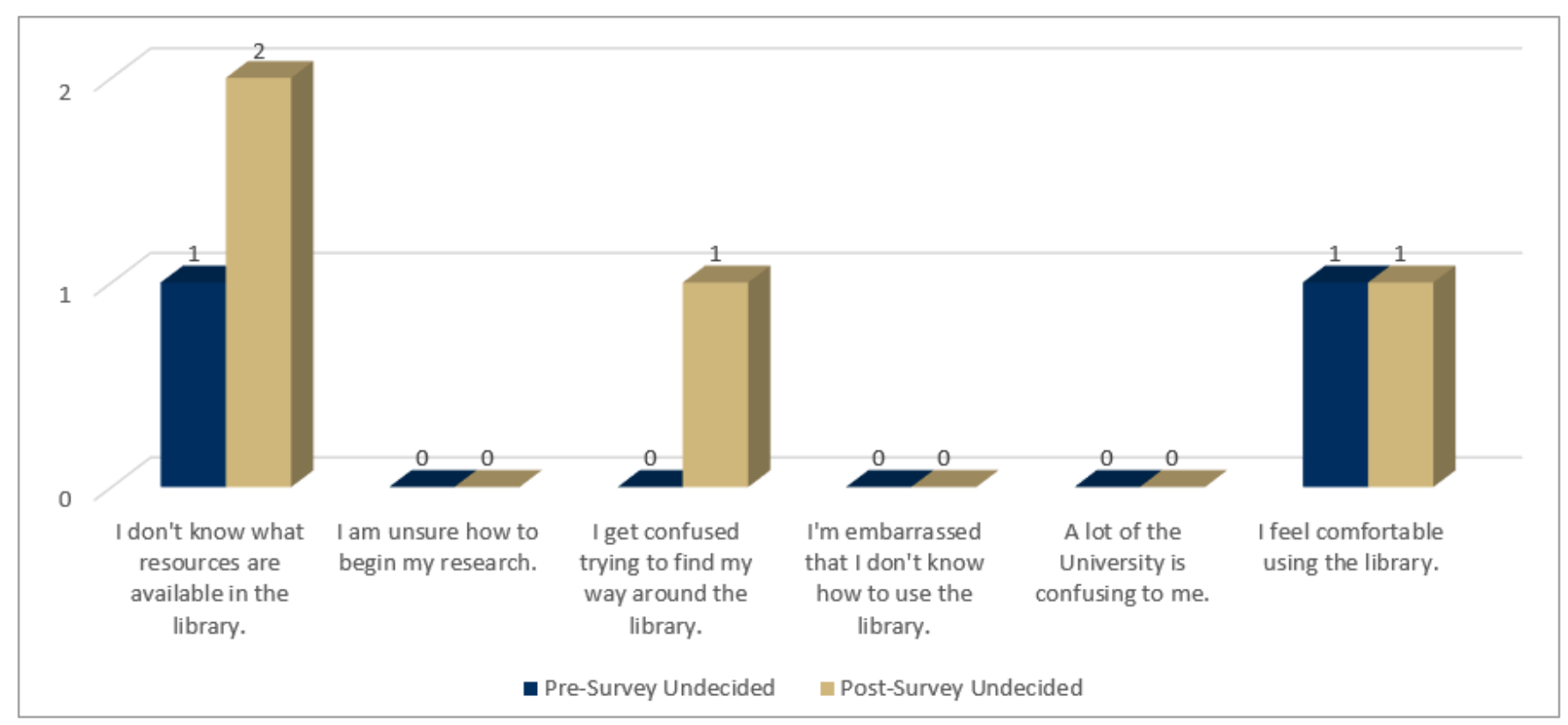

Figure 8.1. Comparison of undecided responses in affective barriers category. 


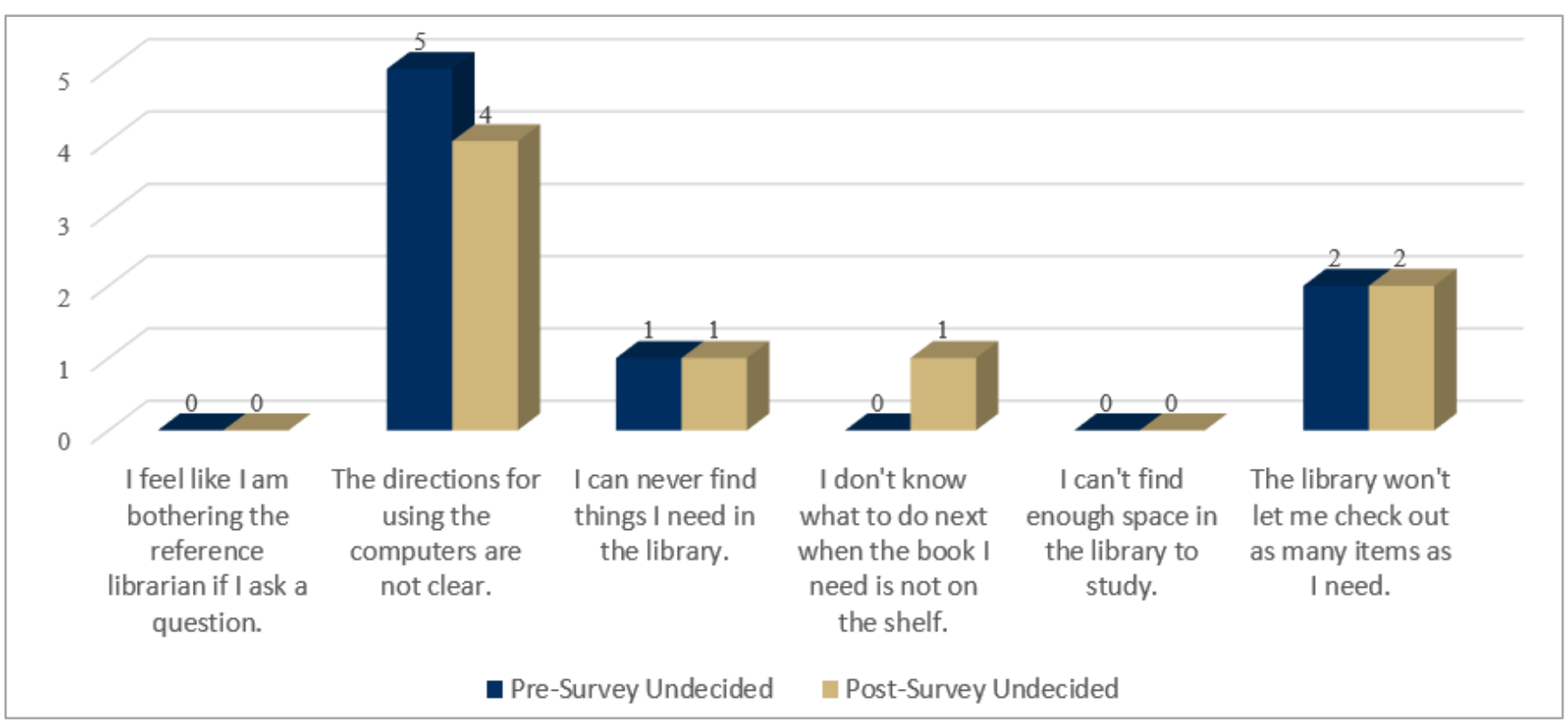

Figure 8.2. Comparison of undecided responses in affective barriers category.

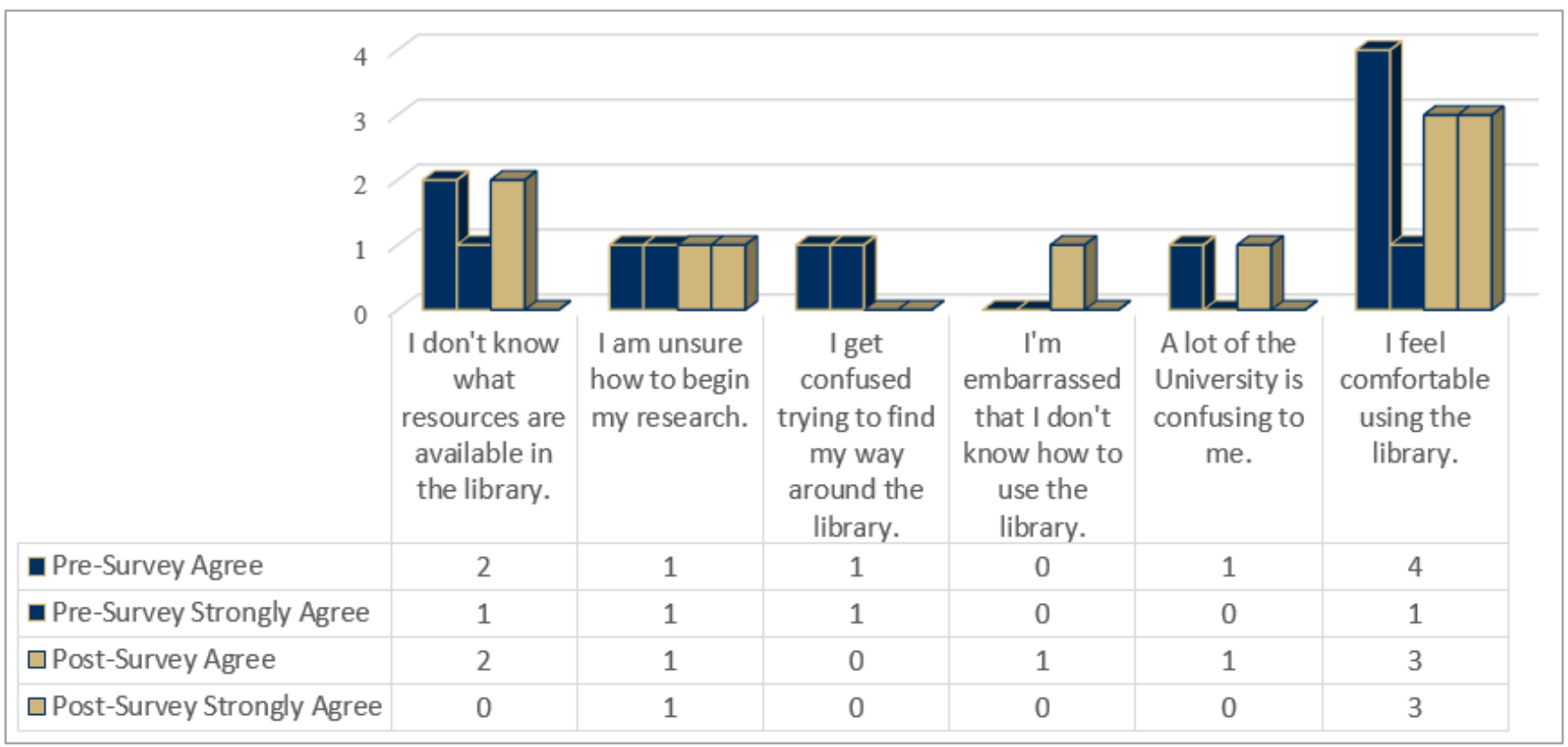

Figure 9.1. Comparison of strongly agree and agree responses in affective barriers category. 


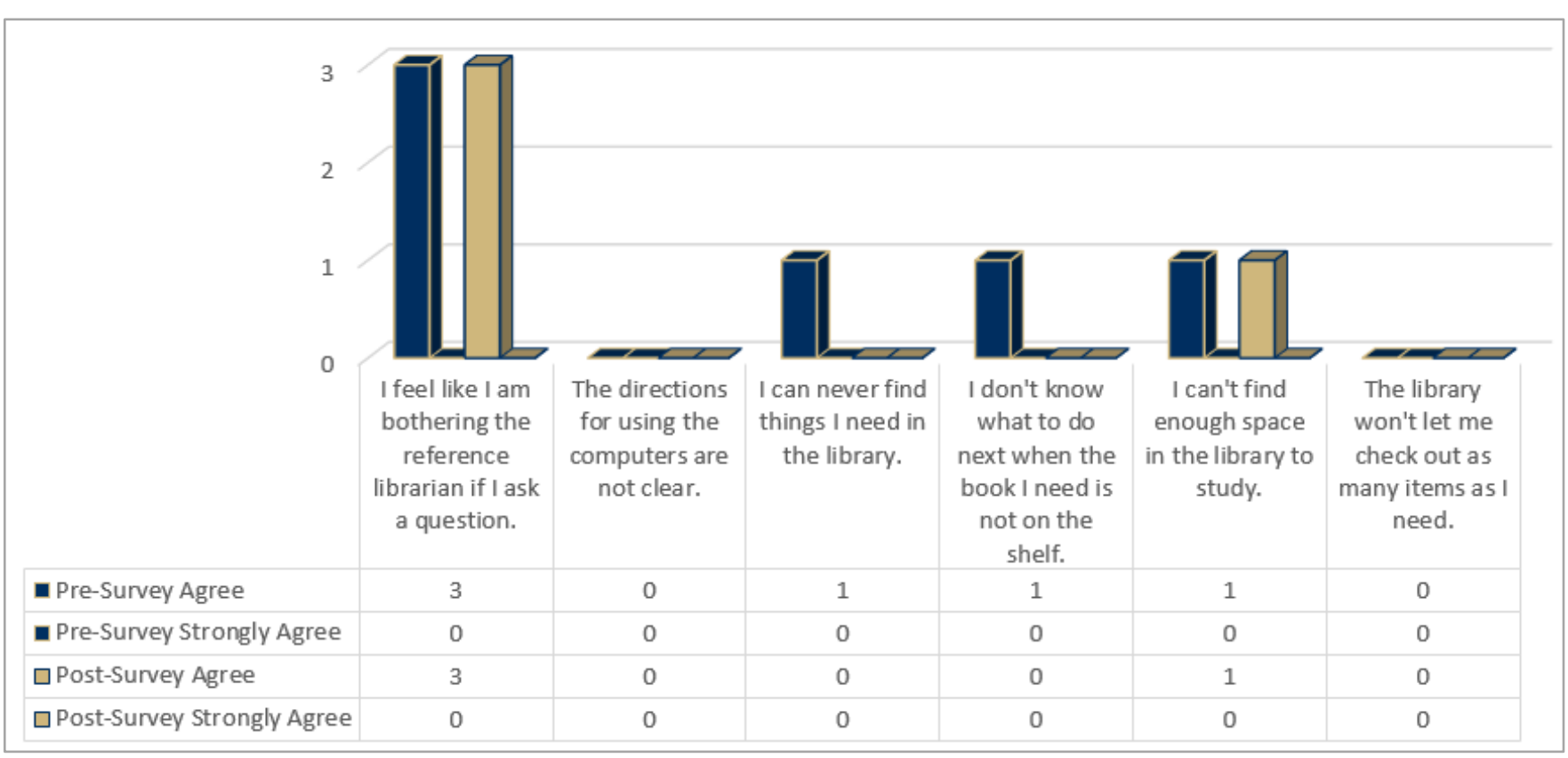

Figure 9.2. Comparison of strongly agree and agree responses in affective barriers category.

\section{Mechanical Barriers}

Although not a goal of the study, there was positive change in participants' responses in both statements in the category of mechanical barriers. It is unclear how the virtual tour might have caused the improvement in participants' perception of the reliability of machines in the library.

\begin{tabular}{lll}
\hline \multicolumn{1}{c}{ Statement } & Positive Negative \\
\hline The computer printers are often out of paper. & 1 \\
The copy machines are usually out of order. & 1 \\
\hline & Totals & 2
\end{tabular}

Table 3. Statements in mechanical barriers category, which showed change on post-survey.

In this category, on both the pre- and post-surveys, there was one strongly disagree response to both statements. No respondents replied agree or strongly agree to the statements in this category. Responses of disagree to both statements increased one from one disagree response on the pre-survey to two disagree responses on the post-survey. The number of undecided responses fell from five to four on the post-survey. As noted above, it is not clear what caused the change in responses.

\section{Barriers with Staff}

A secondary goal of the tour was to reduce barriers with staff and thus to reduce library anxiety by providing information with images of library faculty. By providing information and images of the library faculty, this study sought to reduce the anxiety students may have regarding the accessibility and approachability of library staff. In this category, participants showed some positive effects of the virtual tour on how participants viewed library staff. However, the responses of participants exhibited the most variability in this category, with almost an equal number of responses being positive or negative after viewing the tour. The reasons for this 
variance are unclear. In future studies, additional space for comments will be included on the surveys as well as possible follow-up focus-group discussions to determine the causes of negative trends in responses. Table 4 shows the statements within this category on which participants had a change in their responses from pre- to post-survey. The number in the positive column indicates how many participant responses changed in a favorable direction on the post-survey. The number in the negative column indicates the number of participants whose post-survey responses moved in a negative direction. On the survey instruments, 12 of the 15 statements categorized as Bostick's barriers with staff showed changes in responses.

\begin{tabular}{lrr}
\hline \multicolumn{1}{c}{ Statement } & Positive & Negative \\
\hline I can always ask a librarian if I don't know how to work a piece of & & 1 \\
equipment in the library. & 1 & 1 \\
I can't get help in the library at the times I need it. & 2 & 2 \\
If I can't find a book on the shelf the library staff will help me. & 1 & 1 \\
Library staff don't have time to help me. & 2 & 2 \\
The librarians are unapproachable. & 1 & 3 \\
The library is a comfortable place to study. & 1 & \\
The library staff doesn't care about students. & 2 \\
The library staff doesn't listen to students. & 2 \\
The reference librarians are not approachable. & 1 & 1 \\
The reference librarians are unhelpful. & & \\
The reference librarians don't have time to help me because they're & 2 \\
always busy doing something else. & Totals & 15 \\
There is often no one available in the library to help me. & 12 \\
\hline
\end{tabular}

Table 4. Statements in Barriers with Staff category, which showed change on post-survey.

The findings in the category, overall, were favorable. Most feel the librarians and library staff care and are responsive and available to students. Pre-survey responses indicated one or two of the participants felt librarians are unapproachable or unhelpful. Post-survey responses reflected a positive change in participants' views on librarians' approachability and helpfulness. Participants also reported the library to be a comfortable study location and that the rules are reasonable (figures 10.1, 10.2, 11.1, 11.2, 12.1, 12.2). 


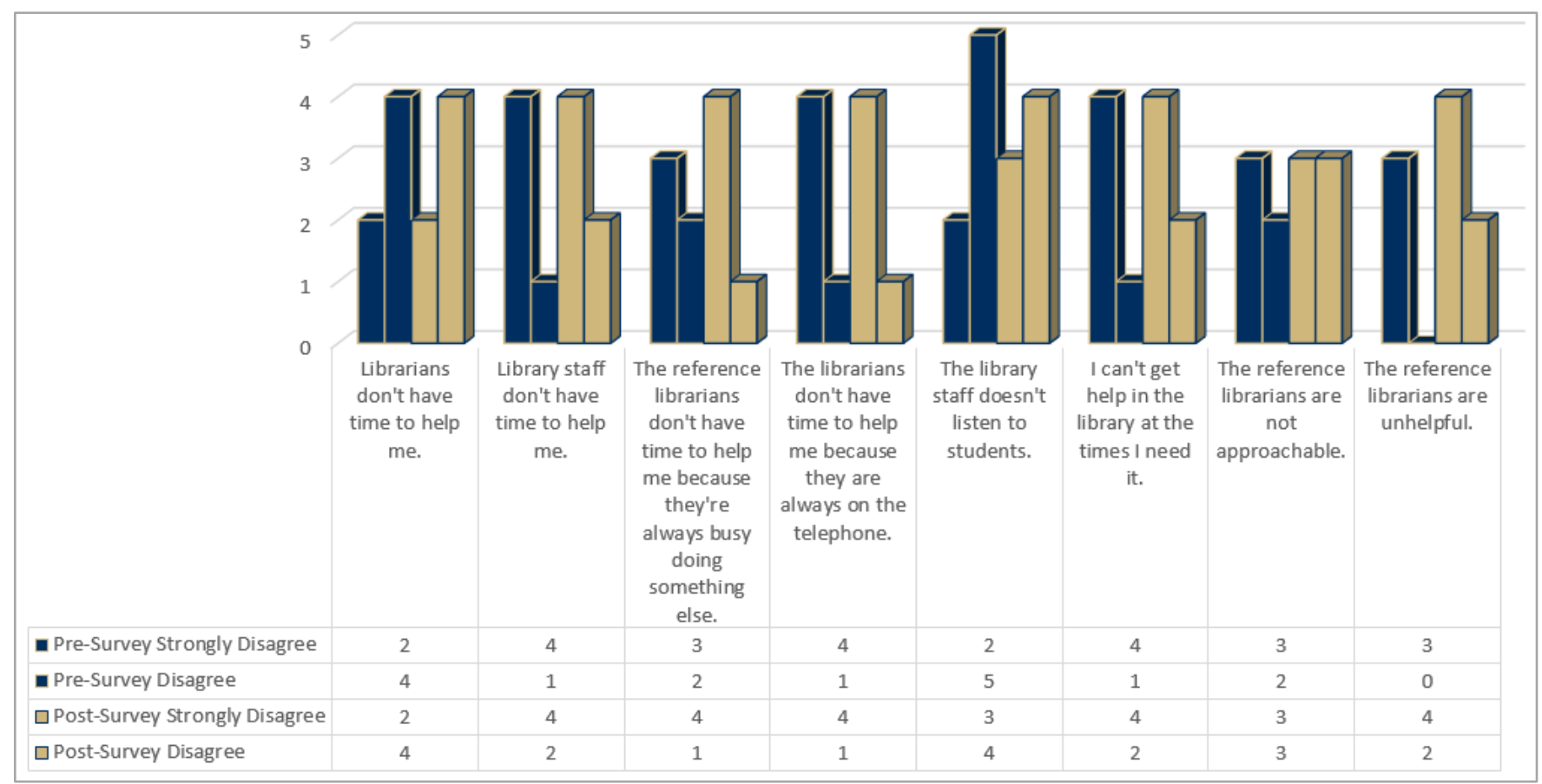

Figure 10.1. Comparison of strongly disagree and disagree responses in barriers with staff category.

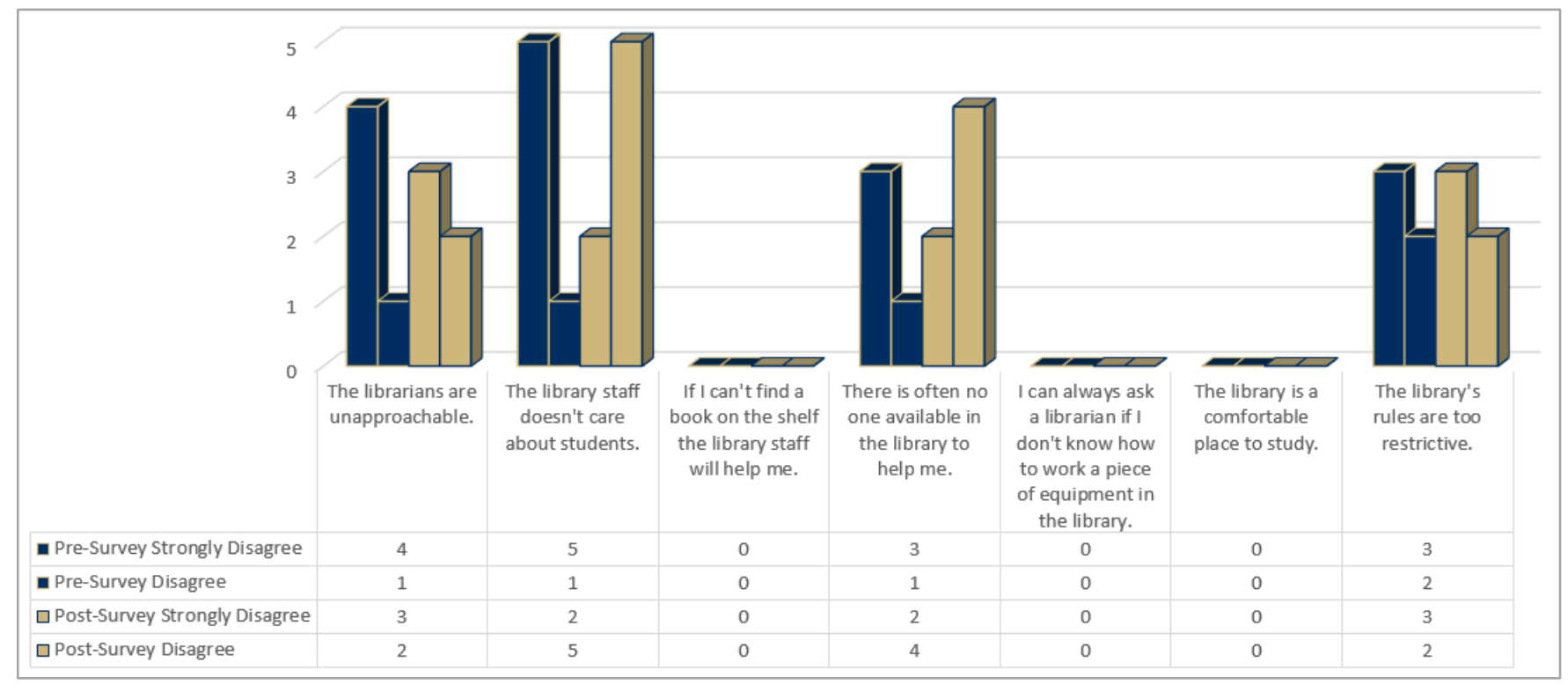

Figure 10.2. Comparison of strongly disagree and disagree responses in barriers with staff category. 


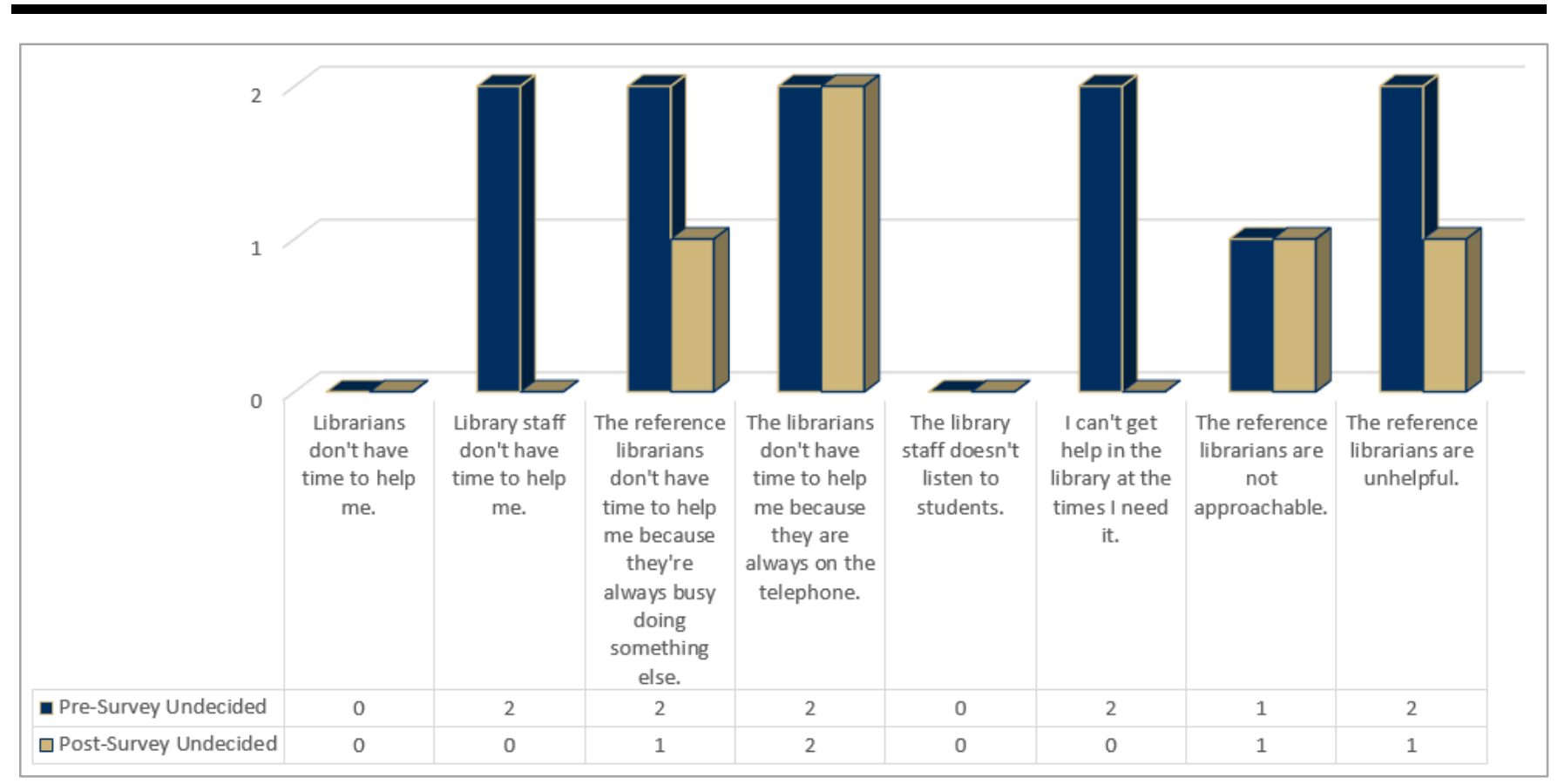

Figure 11.1. Comparison of undecided responses in barriers with staff category.

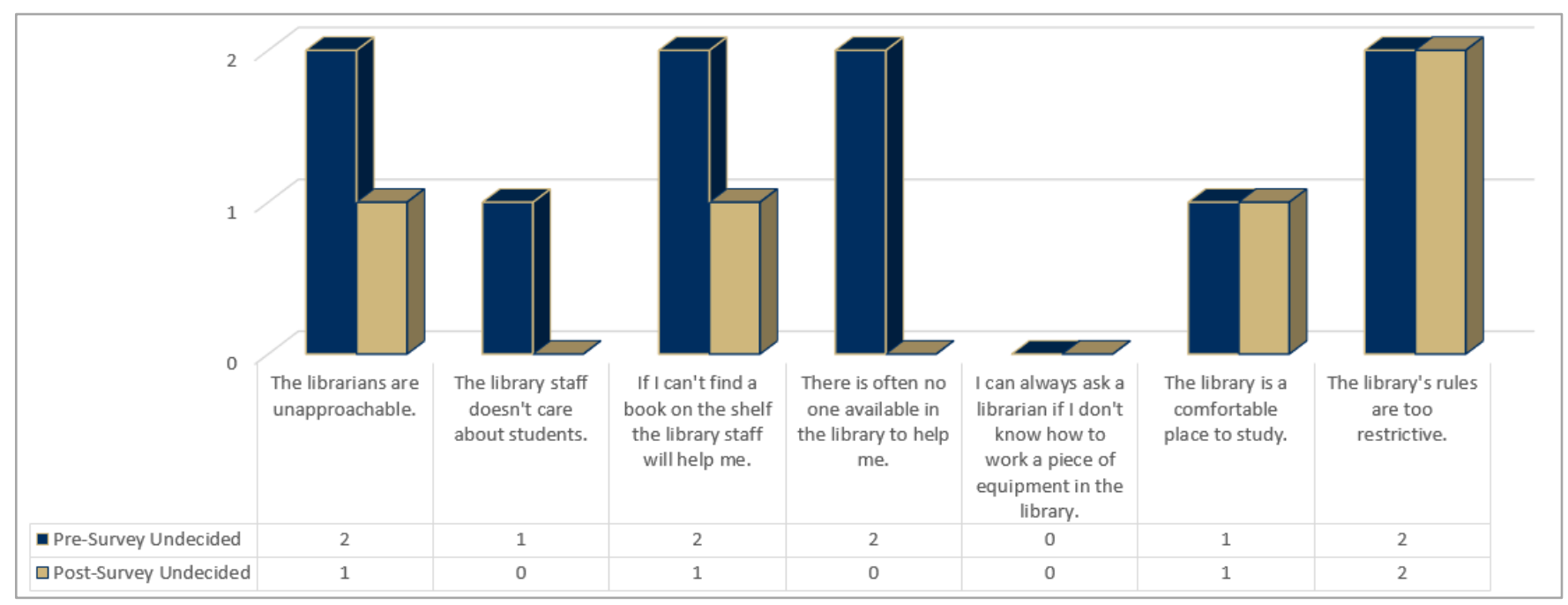

Figure 11.2. Comparison of undecided responses in barriers with staff category. 


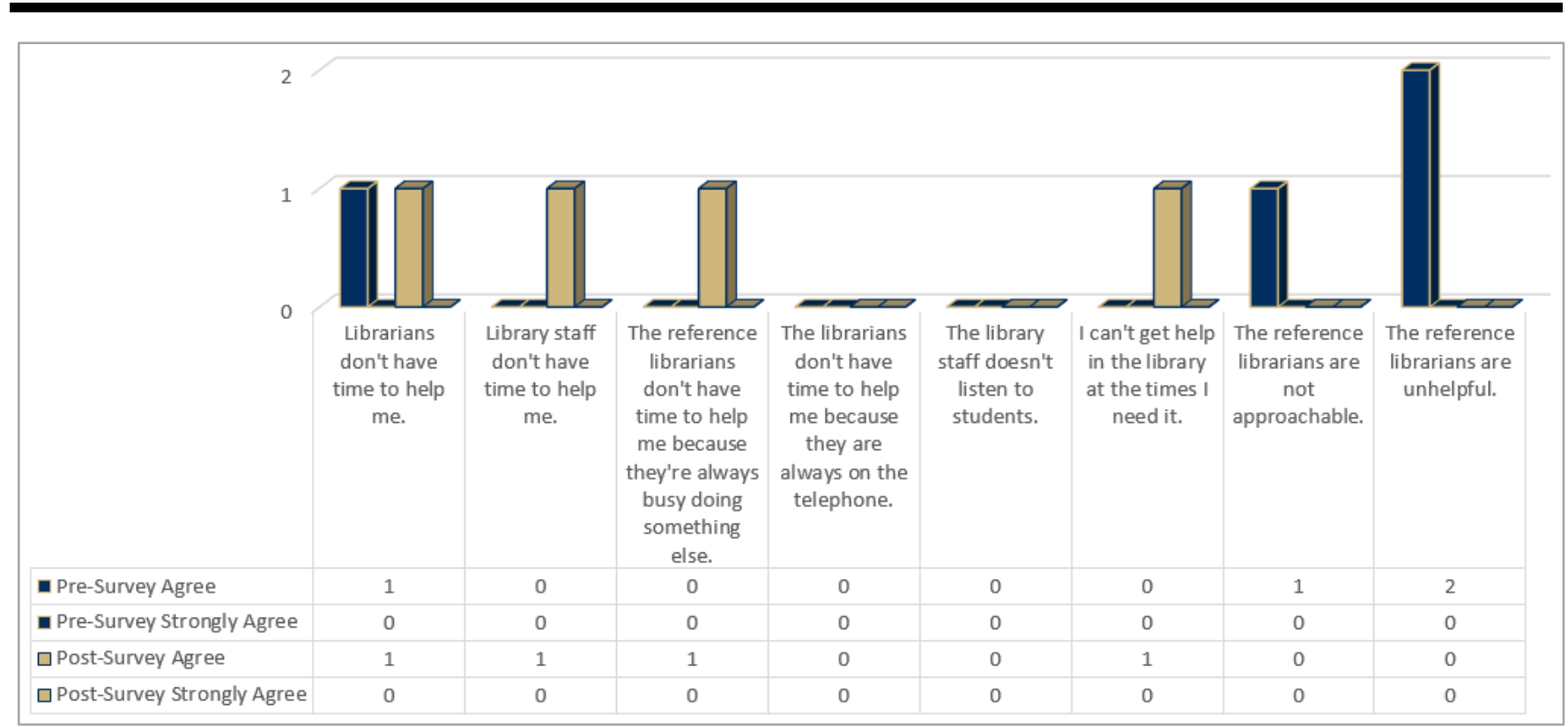

Figure 12.1. Comparison of strongly agree and agree responses in barriers with staff category.

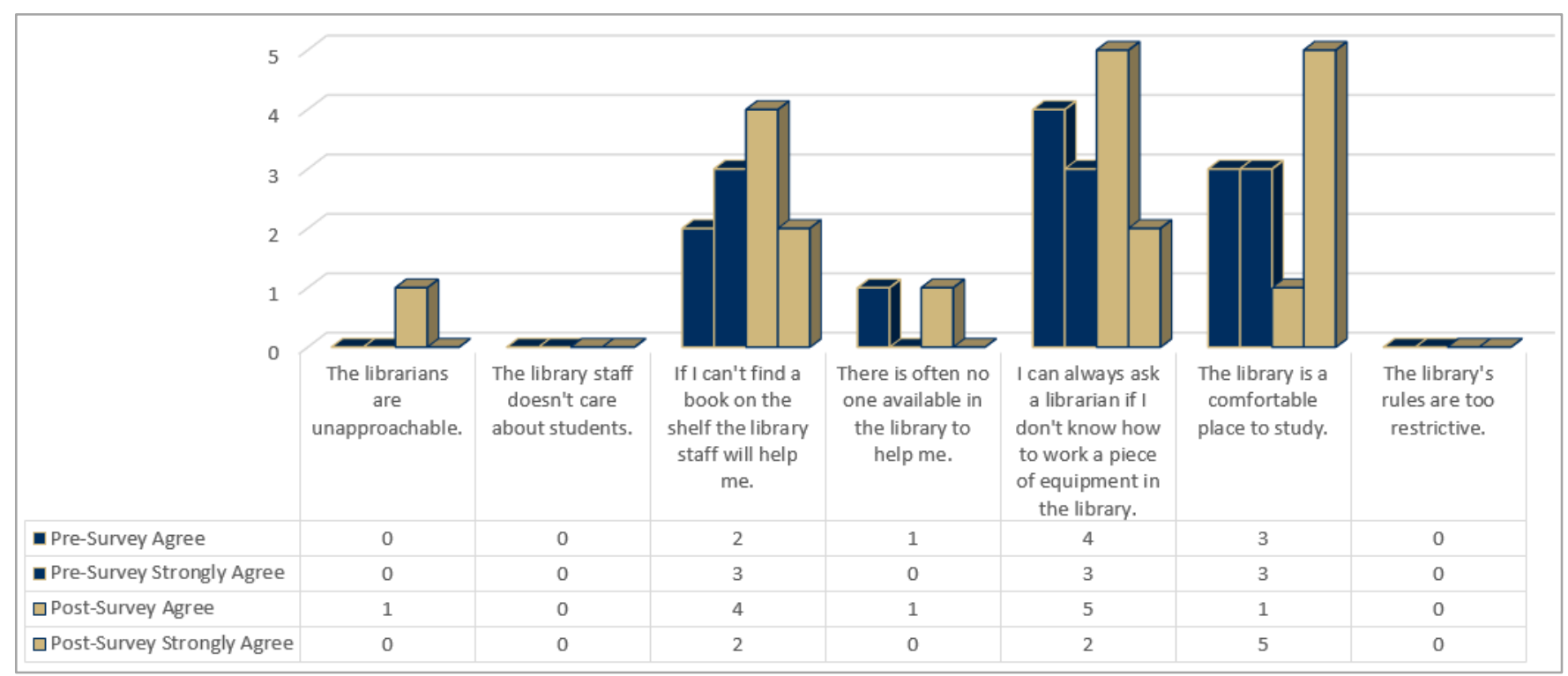

Figure 12.2. Comparison of strongly agree and agree responses in barriers with staff category.

\section{Comfort with the Library}

According to Collins and Veal, comfort with the library is students' perceptions of the library as a "safe and comforting environment." ${ }^{33}$ Out of the 42 statements, Bostick placed 8 within this category, all of whom showed some change in responses from pre-survey to post-survey. The changes reflected in this category were positive, but it is unclear how the virtual tour might have influenced participants' perceptions on statements such as "There is too much crime in the library" or "Good instructions for using the library's computers are available." Further investigation is needed to determine what may account for changes in perception on statements such as these. Table 5 depicts the changes, both positive and negative, in participants' responses on the statements in this category. 


\section{Statement}

Good instructions for using the library's computers are available.

I don't understand the library's overdue fines.

I feel comfortable in the library.

I feel safe in the library.

The library never has the materials I need.

The people who work at the circulation desk are helpful.

The reference librarians are unfriendly.

There is too much crime in the library.

Totals

\section{Positive Negative}

\begin{tabular}{ccc} 
& 1 & 2 \\
& 2 & \\
& 2 & 1 \\
& & 1 \\
& 3 & 1 \\
& 1 & \\
Totals & 1 & 2 \\
\hline
\end{tabular}

Table 5. Statements in comfort with the library category that showed change on post-survey.

The following bar graphs compare the responses on the pre-surveys to the post-survey responses within this category. As with other categories, responses were mostly favorable in this category (figures 13, 14, 15).

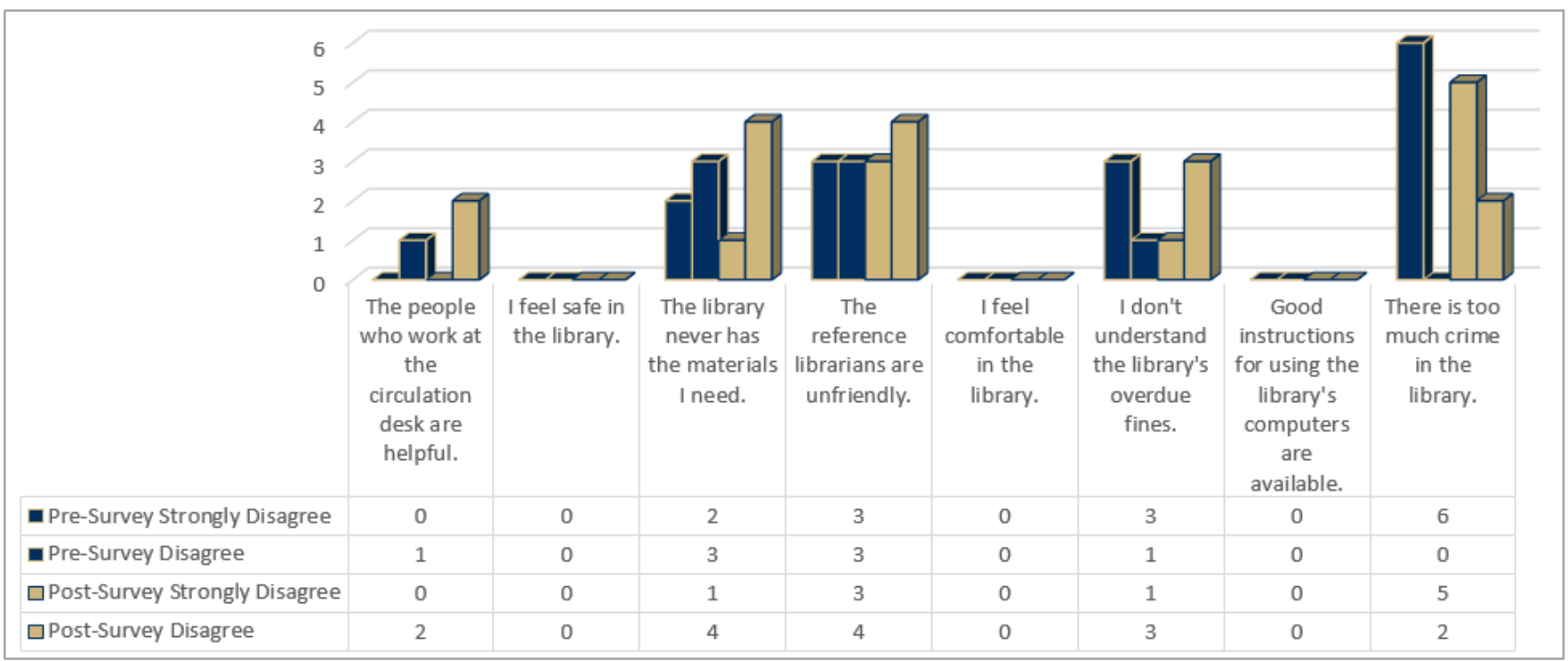

Figure 13. Comparison of strongly disagree and disagree responses in comfort with the library category. 


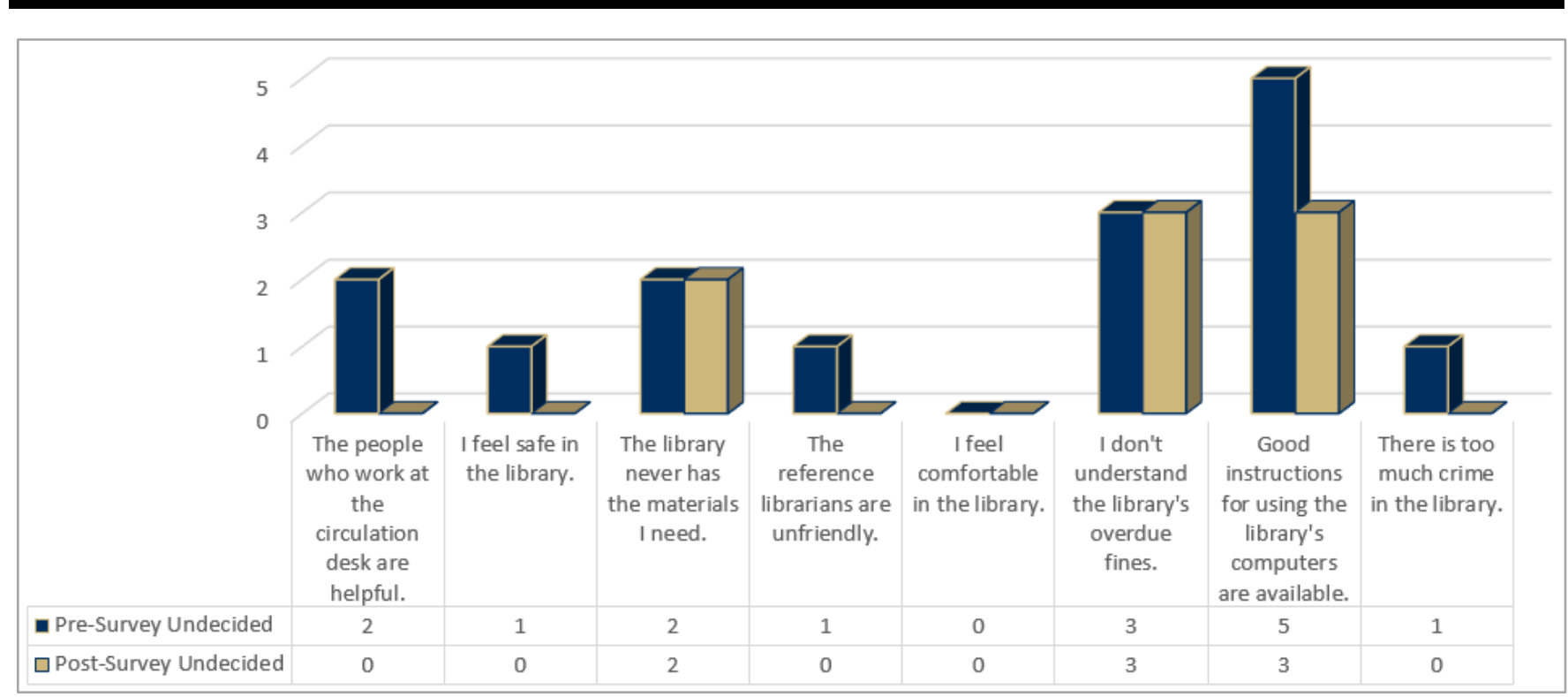

Figure 14. Comparison of undecided responses in comfort with the library category.

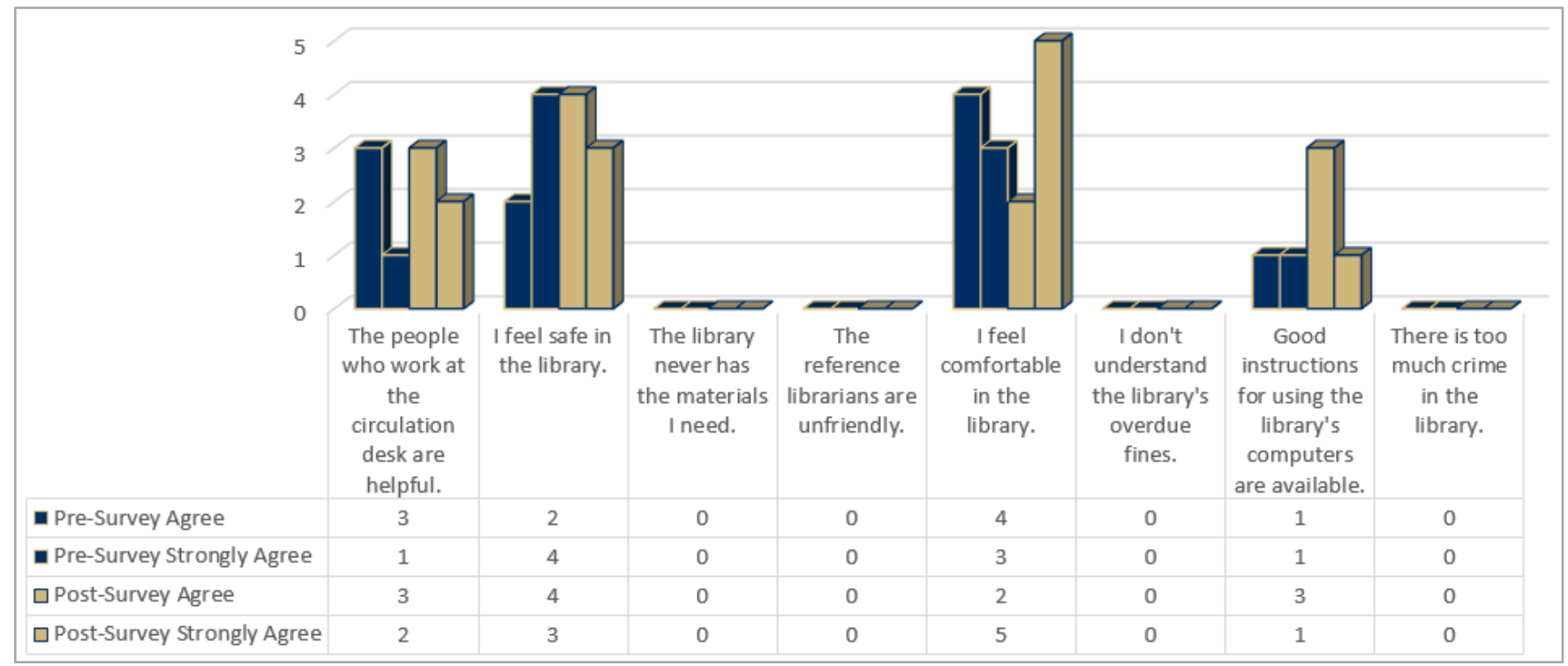

Figure 15. Comparison of strongly agree and agree responses in comfort with the library category.

\section{CONCLUSION}

The ORU Library has found the virtual tour to be of use in familiarizing students with the library. Anecdotal statements from students who viewed the tour during its creation noted the desire that such a tour had been available when they began college and further commented on the assistance that the tour will provide new students.

A limitation of this study is the low participation, with no participation from students from some of the groups that other studies have shown may have higher levels of library anxiety (e.g., new students, international students). However, given the indications of positive effects of the virtual tour from our study results and anecdotal statements, we are encouraged that this tool that will assist our students in reducing library anxiety, with the result that they will visit and use the 
library more often to their benefit. Again, although participation was low, these results have also encouraged ORU librarians to seek other ways to include AVMR and other innovative technologies in our instruction, outreach, and services. The 360 virtual tour of the Library is undergoing updates and additions to provide students with disabilities information on access points and accessible restrooms. Other projects underway include incorporating AVMR in IL sessions, the addition of a digital sandbox with various technologies and equipment including a VR station, and the addition of VR equipment in our designated faculty research room for use by university faculty to learn and teach students how to use AVMR technologies. The response from students and faculty to these new services has been enthusiastic and encouraging that the ORU Library is positively influencing and supporting the academic work of ORU faculty and students.

\section{RECOMMENDED READING}

Varnum, Kenneth J. Beyond Reality: Augmented, Virtual, and Mixed Reality in the Library. Chicago: ALA Editions, 2019.

Elliott, Christine, Marie Rose, and Jolanda-Pieta van Arnhem. Augmented and Virtual Reality in Libraries. Lanham, MD: Rowman \& Littlefield, 2018.

\section{ENDNOTES}

${ }^{1}$ Anthony J. Onwuegbuzie and Qun G. Jiao, "Information Search Performance and Research Achievement: An Empirical Test of the Anxiety-Expectation Mediation Model of Library Anxiety," Journal of the American Society for Information Science \& Technology 55, no. 1 (2004): 41-54, https://doi.org/10.1002/asi.10342; Qun G. Jiao and Anthony J. Onwuegbuzie, "Is Library Anxiety Important?," Library Review 48, no. 6 (1999), https://doi.org/10.1108/00242539910283732; Qun G. Jiao and Anthony J. Onwuegbuzie, Library Anxiety: The Role of Study Habits (paper presented at the Annual Meeting of the MidSouth Educational Research Association (MSERA), Bowling Green, Kentucky, November 15-17, 2000), http://files.eric.ed.gov/fulltext/ED448781.pdf.

${ }^{2}$ Constance A. Mellon, "Library Anxiety: A Grounded Theory and Its Development," College \& Research Libraries 47, no. 2 (1986), https://doi.org/10.5860/crl_47_02_160; see also Constance A. Mellon, "Library Anxiety: A Grounded Theory and Its Development," College \& Research Libraries 76, no. 3 (2015), https://doi.org/10.5860/crl.76.3.276.

${ }^{3}$ Diane Mizrachi, "Library Anxiety," Encyclopedia of Library and Information Sciences (Boca Raton, FL: CRC Press, 2017): 2782.

${ }^{4}$ Mellon, “Library Anxiety,” (1986): 163; see also Mellon, “Library Anxiety,” (2015): 280.

${ }^{5}$ Mellon, “Library Anxiety,” (1986): 162; see also Mellon, “Library Anxiety,” (2015): 278.

${ }^{6}$ Alison J. Head and Michael B. Eisenberg, Truth Be Told: How College Students Evaluate and Use Information in the Digital Age: Project Information Literacy Progress Report (University of Washington's Information School, 2010): 3. 
${ }^{7}$ Sharon Lee Bostick, "The Development and Validation of the Library Anxiety Scale," (PhD diss., Wayne State University, 1992); Qun G. Jiao and Anthony J. Onwuegbuzie, "Antecedents of Library Anxiety," Library Quarterly 67, no. 4 (1997): 72, https://doi.org/10.1086/629972.

${ }^{8}$ Jiao and Onwuegbuzie, "Antecedents of Library Anxiety."

9 Mellon, “Library Anxiety” (1986); see also Mellon, “Library Anxiety” (2015); see also Constance A. Mellon, "Attitudes: The Forgotten Dimension in Library Instruction," Library Journal 113, no. 14 (1988).

${ }^{10}$ Kathleen M. T. Collins and Robin E. Veal, “Off-Campus Adult Learners' Levels of Library Anxiety as a Predictor of Attitudes Toward the Internet," Library \& Information Science Research 26, no. 1 (2004): 4, https://doi.org/https://doi.org/10.1016/j.lisr.2003.11.002.

11 Mizrachi, "Library Anxiety," 2784.

${ }^{12}$ Anthony J. Onwuegbuzie, “Writing A Research Proposal: The Role of Library Anxiety, Statistics Anxiety, and Composition Anxiety," Library \& Information Science Research 19, no. 1 (1997), https://doi.org/10.1016/S0740-8188(97)90003-7.

${ }^{13}$ Carol Collier Kuhlthau, "Developing a Model of the Library Search Process: Cognitive and Affective Aspects," Research Quarterly 28, no. (Winter 1988), https://www.jstor.org/stable/25828262; Carol C Kuhlthau, "Inside the Search Process: Information Seeking from the User's Perspective," Journal of the American Society for Information Science 42, no. 5 (1991), https://doi.org/10.1002/(SICI)10974571(199106)42:5<361::AID-ASI6>3.0.C0;2-\%23.

${ }^{14}$ Shelley Blundell, "Documenting the Information-Seeking Experience of Remedial Undergraduate Students," Proceedings from the Document Academy 1, no. 1 (2014), https://doi.org/10.35492/docam/1/1/4.

${ }^{15}$ Blundell, “Documenting the Information-Seeking Experience,” 5.

16 Blundell, “Documenting the Information-Seeking Experience," 6.

17 Used by permission of the author. Retrieved from http://remedialundergraduateaisp.pbworks.com/w/file/88755941/ModelRevised\%20-\%208 4.jpg.

${ }^{18}$ Blundell, "Documenting the Information-Seeking Experience"; Melissa Gross and Don Latham, "Attaining Information Literacy: An Investigation of the Relationship Between Skill Level, SelfEstimates of Skill, and Library Anxiety," Library \& Information Science Research 29, no. 3 (2007), https://doi.org/10.1016/j.lisr.2007.04.012; Melissa Gross and Don Latham, "Undergraduate Perceptions of Information Literacy: Defining, Attaining, and Self-Assessing Skills," College \& Research Libraries 70, no. 4 (2009), https://doi.org/10.5860/0700336; Melissa Gross and Don Latham, "Experiences With and Perceptions of Information: A Phenomenographic Study of First-Year College Students," Library Quarterly 81, no. 2 (2011), https://doi.org/10.1086/658867; Melissa Gross, "The Impact of Low-Level Skills on 
Information-Seeking Behavior: Implications of Competency Theory for Research and Practice," Reference \& User Services Quarterly (2005), https://www.jstor.org/stable/20864481.

${ }^{19}$ Mellon, “Attitudes,” 138; Jiao and Onwuegbuzie, “Antecedents of Library Anxiety."

${ }^{20}$ Qun G. Jiao and Anthony J. Onwuegbuzie, "Perfectionism and Library Anxiety among Graduate Students," Journal of Academic Librarianship 24, no. 5 (1998), https://doi.org/10.1016/S00991333(98)90073-8; Jiao and Onwuegbuzie, "Is Library Anxiety Important?"; Qun G. Jiao and Anthony J. Onwuegbuzie, "Library Anxiety among International Students" (paper presented at the Annual Meeting of the Mid-South Education Research Association Point Clear, Alabama, November 17-19, 1999), https://eric.ed.gov/?id=ED437973; Qun G. Jiao and Anthony J. Onwuegbuzie, "Self-Perception and Library Anxiety: An Empirical Study," Library Review 48, no. 3 (1999), https://doi.org/10.1108/00242539910270312; Qun G. Jiao and Anthony J. Onwuegbuzie, "Identifying Library Anxiety through Students' Learning-Modality Preferences," Library Quarterly 69, no. 2 (1999), https://doi.org/10.1086/603054; Qun G. Jiao and Anthony J. Onwuegbuzie, Library Anxiety: The Role of Study Habits; Qun G. Jiao and Anthony J. Onwuegbuzie, "Library Anxiety and Characteristic Strengths and Weaknesses of Graduate Students' Study Habits," Library Review 50, no. 2 (2001), https://doi.org/10.1108/00242530110381118; Qun G. Jiao and Anthony J. Onwuegbuzie, "Dimensions of Library Anxiety and Social Interdependence: Implications for Library Services," Library Review 51, no. 2 (2002), https://doi.org/10.1108/00242530210418837; Qun G. Jiao and Anthony J. Onwuegbuzie, The Relationship Between Library Anxiety and Reading Ability (paper presented at the Annual Meeting of the Mid-South Educational Research Association, Chattanooga, Tennessee, November 6-8, 2002), https://eric.ed.gov/?id=ED478612; Qun G. Jiao and Anthony J. Onwuegbuzie, "Reading Ability as a Predictor of Library Anxiety," Library Review 52, no. 4 (2003), https://doi.org/10.1108/00242530310470720; Anthony J. Onwuegbuzie, and Vicki L. Waytowich, "The Relationship between Citation Errors and Library Anxiety: An Empirical Study of Doctoral Students in Education," Information Processing \& Management 44, no. 2 (2008), https://doi.org/10.1016/j.ipm.2007.05.007; Onwuegbuzie, "Writing A Research Proposal"; Anthony J. Onwuegbuzie and Qun G. Jiao, "I'll Go to the Library Later: The Relationship between Academic Procrastination and Library Anxiety," College \& Research Libraries 61, no. 1 (2000), https://doi.org/10.5860/crl.61.1.45; Onwuegbuzie and Jiao, "Information Search Performance and Research Achievement"; Anthony J. Onwuegbuzie, Qun G. Jiao, and Sharon L Bostick, Library Anxiety: Theory, Research, and Applications, vol. 1 (Lanham, Maryland: Scarecrow Press, 2004).

${ }^{21}$ Jiao and Onwuegbuzie, "Identifying Library Anxiety"; Qun G. Jiao, Anthony J. Onwuegbuzie, and Art A. Lichtenstein, "Library Anxiety: Characteristics of 'At-Risk' College Students," Library \& Information Science Research 18, no. 2 (1996), https://doi.org/10.1016/S0740-

8188(96)90017-1; Nahyun Kwon, "A Mixed-Methods Investigation of the Relationship between Critical Thinking and Library Anxiety among Undergraduate Students in Their Information Search Process," College \& Research Libraries 69, no. 2 (2008), https://doi.org/10.5860/crl.69.2.117; Mellon, "Attitudes."

${ }^{22}$ Gaby Haddow, “Academic Library Use and Student Retention: A Quantitative Analysis,” Library \& Information Science Research 35, no. 2 (2013), 
https://doi.org/https://doi.org/10.1016/j.lisr.2012.12.002; Adam Murray, Ashley Ireland, and Jana Hackathorn, "The Value of Academic Libraries: Library Services as a Predictor of Student Retention," College \& Research Libraries 77, no. 5 (2016), https://doi.org/10.5860/crl.77.5.631; Krista M. Soria, "Factors Predicting the Importance of Libraries and Research Activities for Undergraduates," Journal of Academic Librarianship 39, no. 6 (2013), https://doi.org/10.1016/j.acalib.2013.08.017; Krista M Soria, Jan Fransen, and Shane Nackerud, "Library Use and Undergraduate Student Outcomes: New Evidence for Students' Retention and Academic Success," portal: Libraries and the Academy 13, no. 2 (2013), https://doi.org/10.1353/pla.2013.0010; Krista M. Soria, Jan Fransen, and Shane Nackerud, 'Stacks, Serials, Search Engines, and Students' Success: First-Year Undergraduate Students' Library Use, Academic Achievement, and Retention," Journal of Academic Librarianship 40, no. 1 (2014), https://doi.org/10.1016/j.acalib.2013.12.002; Krista M Soria, Jan Fransen, and Shane Nackerud, "Beyond Books: The Extended Academic Benefits of Library Use for FirstYear College Students," College \& Research Libraries 78, no. 1 (2017), https://doi.org/10.5860/crl.78.1.8.

${ }^{23}$ Jiao, Onwuegbuzie, and Lichtenstein, “Library Anxiety,” 1.

${ }^{24}$ Jiao and Onwuegbuzie, "Identifying Library Anxiety"; see also Bostick, "The Development and Validation"; Barbara Fister, Julie Gilbert, and Amy Ray Fry, "Aggregated Interdisciplinary Databases and the Needs of Undergraduate Researchers," portal: Libraries and the Academy 8, no. 3 (2008), https://doi.org/10.1353/pla.0.0003; Mellon, "Library Anxiety"; Jiao and Onwuegbuzie, "Perfectionism and Library Anxiety among Graduate Students"; Jiao and Onwuegbuzie, "Is Library Anxiety Important?"; Jiao and Onwuegbuzie, "Library Anxiety among International Students"; Jiao and Onwuegbuzie, "Self-Perception and Library Anxiety: An Empirical Study"; Jiao and Onwuegbuzie, "Identifying Library Anxiety through Students' Learning-Modality Preferences"; Jiao and Onwuegbuzie, Library Anxiety: The Role of Study Habits; Jiao and Onwuegbuzie, "Library Anxiety and Characteristic Strengths and Weaknesses of Graduate Students' Study Habits"; Jiao and Onwuegbuzie, "Dimensions of Library Anxiety and Social Interdependence"; Jiao and Onwuegbuzie, The Relationship Between Library Anxiety and Reading Ability; Jiao and Onwuegbuzie, "Reading Ability as a Predictor of Library Anxiety"; Onwuegbuzie and Waytowich, "The Relationship between Citation Errors and Library Anxiety"; Onwuegbuzie, "Writing A Research Proposal"; Onwuegbuzie and Jiao, "I'll Go to the Library Later"; Onwuegbuzie and Jiao, "Information Search Performance and Research Achievement"; Onwuegbuzie, Jiao, and Bostick, Library Anxiety: Theory, Research, and Applications.

${ }^{25}$ Onwuegbuzie and Jiao, "The Relationship"; Anthony Onwuegbuzie and Qun G. Jiao, "Understanding Library-Anxious Graduate Students," Library Review 47, no. 4 (1998), https://doi.org/10.1108/00242539810212812.

${ }^{26}$ Jiao and Onwuegbuzie, "Is Library Anxiety Important?"

${ }^{27}$ Qun G. Jiao, Anthony J. Onwuegbuzie, and Sharon L Bostick, "Racial Differences In Library Anxiety among Graduate Students," Library Review 53, no. 4 (2004), https://doi.org/10.1108/00242530410531857; Qun G. Jiao, Anthony J. Onwuegbuzie, and Sharon L. Bostick, "The Relationship Between Race and Library Anxiety among Graduate 
Students: A Replication Study," Information Processing \& Management 42, no. 3 (2006), https://doi.org/10.1016/j.ipm.2005.03.018.

${ }^{28}$ Mizrachi, “Library Anxiety,” 2784.

${ }^{29}$ Anthony J. Onwuegbuzie and Qun G. Jiao, "Academic Library Useage: A Comparison of Native and Non-Native English-Speaking Students," Australian Library Journal 46, no. 3 (1997): 263, https://doi.org/10.1080/00049670.1997.10755807; Jiao and Onwuegbuzie, "Antecedents of Library Anxiety."

${ }^{30}$ Jiao and Onwuegbuzie, "Library Anxiety among International Students."

31 Yunhui Lu and Denice Adkins, "Library Anxiety among International Graduate Students," Proceedings of the American Society for Information Science and Technology 49, no. 1 (2012), https://doi.org/10.1002/meet.14504901319.

${ }^{32}$ Collins and Veal, "Off-Campus Adult."

${ }^{33}$ Nahyun Kwon, Anthony J. Onwuegbuzie, and Linda Alexander, "Critical Thinking Disposition and Library Anxiety: Affective Domains on the Space of Information Seeking and Use in Academic Libraries," College \& Research Libraries 68, no. 3 (2007): 276, https://doi.org/10.5860/crl.68.3.268.

${ }^{34}$ Kwon, "A Mixed-Methods Investigation."

35 Judy Carol Bell, "Student Affect Regarding Library-Based and Web-Based Research Before and After an Information Literacy Course," Journal of Librarianship \& Information Science 43, no. 2 (2011), https://doi.org/10.1177/0961000610383634.

${ }^{36}$ Jessica Platt and Tyson L Platt, "Library Anxiety among Undergraduates Enrolled in a Research Methods in Psychology Course," Behavioral \& Social Sciences Librarian 32, no. 4 (2013): 248, https://doi.org/10.1080/01639269.2013.841464.

${ }^{37}$ Rachel A. Fleming-May, Regina Mays, and Rachel Radom, “'I Never Had to Use the Library in High School': A Library Instruction Program for At-Risk Students," portal: Libraries and the Academy 15, no. 3 (2015), https://doi.org/10.1353/pla.2015.0038.

${ }^{38}$ Catherine Pellegrino, "Does Telling Them to Ask for Help Work?," Reference \& User Services Quarterly 51, no. 3 (2012), https://doi.org/10.5860/rusq.51n3.272.

${ }^{39}$ Kathy Christie Anders, Stephanie J. Graves, and Elizabeth German, "Using Student Volunteers in Library Orientations," Practical Academic Librarianship: The International Journal of the SLA 6, no. 2 (2016): 17-30, http://hdl.handle.net/1969.1/166249.

${ }^{40}$ Pamela N. Martin and Lezlie Park, "Reference Desk Consultation Assignment: An Exploratory Study of Students' Perceptions of Reference Service," Reference \& User Services Quarterly 49, no. 4 (2010), https://doi.org/10.5860/rusq.49n4.333. 
${ }^{41}$ Sarah McDaniel, "Library Roles in Advancing Graduate Peer-Tutor Agency and Integrated Academic Literacies," Reference Services Review 46, no. 2 (2018), https://doi.org/10.1108/RSR-02-2018-0017.

${ }^{42}$ Elaine M. Robbins, "Breaking the Ice: Using Non-Traditional Methods of Student Involvement to Effect [sic] a Welcoming College Library Environment," Southeastern Librarian 62, no. 1 (2014), https://digitalcommons.kennesaw.edu/seln/vol62/iss1/5.

${ }^{43}$ Elizabeth DiPrince et al., “Don’t Panic!,” Reference \& User Services Quarterly 55, no. 4 (2016), https://doi.org/10.5860/rusq.55n4.283.

44 Oral Roberts University, “About ORU,” (2019), https://www.oru.edu/admissions/undergraduate/.

${ }^{45}$ Oral Roberts, Our Partnership with God [sound recording]. Eighth World Outreach, Oral Roberts Evangelistic Association, Tulsa, OK: Abundant Life Recordings, 1962).

${ }^{46}$ Oral Roberts, Our Partnership.

${ }^{47}$ Margaret M. Grubiak, "An Architecture for the Electronic Church: Oral Roberts University in Tulsa, Oklahoma," Technology and Culture 57, no. 2 (2016), https://doi.org/10.1353/tech.2016.0066.

${ }^{48}$ Stephanie Hill, “ORU Receives Innovation Award,” press release, May 2, 2017, http://www.oru.edu/news/oru_news/20170502-glc-innovation-award.php?locale=en.

${ }^{49}$ Hill, "ORU Receives."

${ }^{50}$ Bostick, “The Development and Validation," 160.

${ }^{51}$ Blundell, “Documenting the Information-Seeking Experience,” 263.

52 Mizrachi, “Library Anxiety,” 2784.

${ }^{53}$ Collins and Robin E. Veal, "Off-Campus Adult,” 7. 